\title{
Courts, Covenants, and Communities
}

\author{
Clayton P. Gillette†
}

The dramatic rise of residential associations ${ }^{1}$ gives reason to believe that both the blessing and the curse of decentralization can be realized more fully within these communities than through more traditional local governments. Both consequences follow from the fact that associations allow individuals with common preferences to gravitate to a common location where they can pursue their conception of the good life. The blessing of this possibility is illustrated by Chief Justice Burger's dissent in Schad $v$ Borough of Mount Ephraim. ${ }^{2}$ The majority in that case invalidated, on First Amendment grounds, a zoning ordinance that prohibited live entertainment and that was directed specifically at nude dancing. But to the Chief Justice, First Amendment interests had no clear priority over the desires of residents within a small community who wished to be "masters of their own environment." Hence, the borough's exercise of its zoning power "to provide a setting of tranquility" was nothing more than a legiti-

$\dagger$ Perre Bowen Professor of Law and Caddell and Conwell Research Professor, University of Virginia School of Law. I owe thanks to Lillian BeVier, Mary Anne Case, Ronald Cass, Jane Cohen, Doug Leslie, Saul Levmore, Dan Ortiz, Glen Robinson, Lawrence Sager, Elizabeth Scott, Robert Scott, Rip Verkerke, and participants in faculty workshops at Boston University School of Law and the University of Virginia School of Law. For purposes of full disclosure, the reader may want to note that the author is a member of the Board of Directors of the Bellair Homeowners Association in Albemarle County, Virginia.

1 By the end of the [1980s], there were more than 130,000 [residential community associations ("RCAs")] operating in the United States and more than 30 million Americans were subject to RCA governance. The number of RCAs in the United States is currently increasing by approximately 9,500 annually and is expected to reach 225,000 by the year 2000 . Assuming that the RCAs created in the next few years are approximately the same size as those already in existence (approximately 230 residents per $\mathrm{RCA}$ ), the number of Americans subject to RCA governance will grow by approximately 2.1 million annually and will exceed 50 million by the year 2000.

Robert Jay Dilger, Neighborhood Politics: Residential Community Associations in American Governance 5 (NYU, 1992) (citations omitted). See also Advisory Commission on Intergovernmental Relations, Residential Community Associations: Private Governments in the Intergovernmental System? 1, 3-4 (1989) ("ACIR Report").

2452 US 61, 85 (1981).

3 Id at 85. 
mate attempt "to preserve the basic character of [the] community." Refusal to permit residents "to shape their community so that it embodies their conception of the "decent life" would, in Burger's view, destroy the diversity of local communities and force all localities into "a mold cast by this Court." Perhaps it is imputing too much to Burger's sympathetic view of small-town life, but his appeals to mastery and to diversity seem to incorporate many of the more academic justifications of decentralization: the creation of opportunities for self-government, the opportunity to generate a mutually respectful heterogeneity within the larger society, ${ }^{6}$ and-perhaps most relevant for current purposes-the creation of an institution that the individual can identify more closely with than an impersonal and distant centralized state.

The curse that confronts this idyllic view of small communities is evident in those critiques of localism that view the pursuit of a common vision of the good life as inherently exclusionary. Moreover, they contend, the bases of exclusion tend to reflect selfishness, wealth, or ethnicity rather than a unique preference for particular local public goods or an idiosyncratic, but benign, lifestyle. ${ }^{7}$ While they do not necessarily ignore the possible virtues of decentralization, these critiques of localism further imply that achievement of those objectives requires satisfaction of highly idealized assumptions about wealth, mobility, and the external effects of local decisions that seem inconsistent with contemporary urban experience. ${ }^{8}$ Since not all individuals can live where they prefer, decentralization for the select few will encourage them to seek isolation from the fiscal and physical burdens of urban life instead of working for the improvement of the larger community. Where communitarians imply that local-

Id at $85-86$.

5 Id at 87.

6 See Jerry Frug, Decentering Decentralization, 60 U Chi L Rev 253 (1993). For criticism of Chief Justice Burger's view as centered on conceptions of the good that can only be pursued by some segment of the population, see Robert Douglas Chesler, Imagery of Community, Ideology of Authority: The Moral Reasoning of Chief Justice Burger, 18 Harv CR-CL L Rev 457 (1983).

7 See Gary J. Miller, Cities by Contract: The Politics of Municipal Incorporation 3741, 63 (MIT, 1981); Richard Briffault, Our Localism: Part I-The Structure of Local Government Law, 90 Colum L Rev 1 (1990); Richard Briffault, Our Localism: Part II-Localism and Legal Theory, 90 Colum L Rev 346 (1990); Lawrence Gene Sager, Tight Little Islands: Exclusionary Zoning, Equal Protection, and the Indigent, 21 Stan L Rev 767 (1969).

$B$ These assumptions are consistent with those made in the classic article by Charles M. Tiebout, A Pure Theory of Local Expenditures, 64 J Pol Econ 416 (1956), which specifies the conditions for an ideal allocation of local public goods. 
ism can embody commitments to mutual respect among different groups, the critiques respond with skepticism that the required levels of toleration and altruism can be realized. ${ }^{9}$

Thus, we suffer, in the words of one commentator, from the "instincts of inclusion and exclusion."10 Because both the blessing of a participatory, communal system in which individuals can pursue their goals and the curse of irresponsible isolation from needy neighbors are entrenched in the way we think of our society, we face substantial ambivalence about attempts to carve out enclaves that depart from majoritarian norms. Our ambivalence toward communities is apparent in an inconsistent and often disconnected series of constitutional law decisions that sometimes allow, and sometimes prohibit, majority interference with the practices and preferences of discrete ways of life. ${ }^{11}$

In this Article, I argue that nonconstitutional doctrines also reflect our ambivalence about decentralized communities. My interests here lie in judicial review of the efforts of residential associations, primarily homeowners associations, to define their members' lifestyles in ways akin to the use of ordinances by traditional local governments. Local governments assume identities by selecting a particular basket of goods and services at particular tax prices, and then regulating the activity of those who are attracted by the goods and services offered. Yet the size of contemporary cities, combined with legal doctrines and political obstacles that prevent localities from differentiating among residents for purposes of service provision, drives some individuals to seek more decentralized institutions to satisfy the search for a specialized service package.

9 See, for example, Amy Gutmann, Communitarian Critics of Liberalism, 14 Phil \& Pub Aff 308, 318-320 (1985) ("[C]ommunitarian critics want us to live in Salem, but not to believe in witches."); Stephen Holmes, The Permanent Structure of Antiliberal Thought, in Nancy L. Rosenblum, ed, Liberalism and the Moral Life 227, 230-32 (Harvard, 1989).

${ }^{10}$ Frug, $60 \mathrm{U}$ Chi L Rev at 291 (cited in note 6).

1 See, for example, Church of the Lukumi Babalu Aye, Inc. $v$ City of Hialeah, $113 \mathrm{~S}$ Ct 2217 (1993) (invalidating, under the Free Exercise Clause, a city ordinance directed at religious practice of ritual sacrifice of animals); Wisconsin $v$ Yoder, 406 US 205 (1972) (exempting the Amish from a state law requiring high school attendance until the age of sixteen); Santa Clara Pueblo v Martinez, 436 US 49 (1978) (allowing a Native American tribe to determine its own membership even though the qualifications discriminate against women); Village of Belle Terre $v$ Boraas, 416 US 1 (1974) (upholding an ordinance restricting land use to one-family dwellings); Moore $v$ East Cleveland, 431 US 494 (1977) (invalidating a one-family dwelling ordinance); State of Oregon $v$ City of Rajneeshpuram, 598 F Supp 1208 (D Or 1984) (invalidating the incorporation of a city dedicated to a religious purpose); Cleburne v Cleburne Living Center, 473 US 432 (1985) (invalidating an ordinance requiring group homes for the mentally retarded to obtain special use permits). 
The very fact that residential associations can fulfill the goals that we identify with traditional local governments makes us more skeptical of conferring on them the latitude that we grant to other voluntary associations, such as the Boy Scouts, the Rotary Club, the country club, or a law firm partnership. ${ }^{12}$ There seems an initial incongruity about applying different standards to review the same kind of directive (for example, aesthetic regulation of architectural styles for residences), depending on whether the regulator is a private association or a municipality.

But our desire to obtain the benefits of community-participation, connectedness to others-seems to demand greater tolerance of associations that purport to serve a narrow, self-defined constituency. The strength of the claim for tolerance may depend on the extent to which we believe that those who reside in small communities have significant interactions with outsiders or are isolated from nonmembers. The communitarian critique of the atomistic premises of liberalism relies in large part on the theory that individuals form their preferences and their identities through social interactions. ${ }^{13}$ Residential associations that are occupied by homogeneous populations (typically by those best off within the society) and whose members eschew the

12 See, for example, Welsh v Boy Scouts of America, 993 F2d 1267 (7th Cir 1993), cert denied, 114 S Ct 602 (1993) (holding that the Boy Scouts are not subject to a public accommodation statute). This is not to say that we do not sometimes regulate these associations. See, for example, Hishon $v$ King \& Spalding, 467 US 69 (1984) (requiring the consideration of women for partnership in a law firm); Ruich $v$ Ruff, Weidenaar \& Reidy, 837 F Supp 881 (N D Ill 1993) (holding a law firm partner subject to individual liability under Title VII); New York State Club Ass'n v City of New York, 69 NY2d 211, 505 NE2d 915 (1987) (upholding an antidiscrimination law applied to "private" clubs); Quinnipiac Council, Boy Scouts of America v Comm'n on Human Rights and Opportunities, 204 Conn 287, 528 A2d 352 (1987) (holding the Boy Scouts subject to a public accommodation statute); Rotary International $v$ Rotary Club of Duarte, 481 US 537 (1987) (upholding a statute requiring Rotary Clubs to admit women); United States $v$ Lansdowne Swim Club, 713 F Supp 785 (E D Pa 1989) (prohibiting discriminatory membership policies by a swim club). Nor do I want to overstate the private nature of private associations, which may often be used to accomplish public purposes. See Hendrik Hartog, Public Property and Private Power (Cornell, 1983) (noting the role of officials of New York City, which was largely a private corporation in the eighteenth century, in the development of modern municipal law and its accompanying justifications for local public action); Arthur J. Jacobson, The Private Use of Public Authority: Sovereignty and Associations in the Common Law, 29 Buff L Rev 599 (1981).

${ }_{13}$ See, for example, Michael J. Sandel, Liberalism and the Limits of Justice 11-13 (Cambridge, 1982); Michael Walzer, Spheres of Justice 312-13 (Basic Books, 1983); Gregory S. Alexander, Dilemmas of Group Autonomy: Residential Associations and Community, 75 Cornell L Rev 1, 35-36 (1989); Frug, $60 \mathrm{U}$ Chi L Rev at 260 (cited in note 6). For an application to cities, see Gordon L. Clark, Judges and the Cities 27-32 (Chicago, 1985). 
company of outsiders may be considered the archetypal representatives of self-interested liberalism. But if residents of associations enjoy interactions with others at work, in social contexts, or in politics (to name some alternatives), then the fact that they seek a more private preserve for interactions with a more homogeneous population does not necessarily translate into a narrowly self-interested lifestyle. ${ }^{14}$

Residential associations, small enough to disaggregate desirable from undesirable services and uniform enough to create enclaves of social security, may satisfy both these objectives. Indeed, I take it that part of the project for communitarians in law is to nurture distinct communities while finding common ground among seemingly exclusive groups, to "help undermine the power of suburban consciousness by organizing interlocal negotiations to highlight these contradictory instincts." ${ }^{215}$ If that is the case, then the combination of homogeneous residential associations and interaction with diverse groups in other contexts may actually serve the communitarian goal (although I suspect that the residential association would constitute too thin of a community to satisfy many communitarians).

Notwithstanding my implicit assumption that associations attract similarly situated individuals, migration to a common locality does not mean arrival at a frictionless society. Members of homeowners associations may conflict with each other or, as a group, with outsiders. Residents may find that their concept of the good life is less consistent with that of their neighbors than they had originally believed, or that it falls so far from majoritarian norms as to provoke the active disapproval of nonresidents. Thus, disputes are likely to arise as residents of an association implement their vision of their community or its relationship to nonresidents. It is through resolution of these disputes that the legal system reveals the value we ultimately place on autonomous associations. The more that we value the development of communities that have selected either a discrete package of goods and services or that have opted for a more privatized form of regulation than that offered by traditional municipalities, the more the law should defer to associations as

14 Of course, this might not be the case. A residential association that appeals to retirees, for instance, may provide all the social, political, and economic activities that residents require. See Frances FitzGerald, Cities On a Hill 203-45 (Simon and Schuster, 1986) (describing self-contained life in the retirement community of Sun City, Florida).

15 Frug, 60 U Chi L Rev at 290-91 (cited in note 6). 
they seek to regulate their members. On the other hand, if we consider either the objectives or the decision-making processes of these institutions to be suspect, we presumably would limit our deference.

I want to introduce one additional puzzle before examining the legal responses to these issues. One of the salient characteristics of community life is the capacity to exclude along lines that are selected by the community itself. ${ }^{16}$ The explicit bases of exclusion with which $I$ am concerned focus less on the discredited efforts of associations to create islands of ethnic harmony than on common ventures to attain the assumed pleasures of suburban life, free from satellite dishes, trailer homes, tall fences, or commercial vehicles. These criteria for exclusion do not necessarily carry the weighty social consequences of racial or religious discrimination (unless we believe they are merely surrogates for prohibited classifications). They are instead characteristic of the "ordinary vices"17 of economically or socially exclusive organizations. Yet the negative reactions to homeowners associations appear to be predicated on these forms of exclusion.

At the same time, both liberals and communitarians seem to be tolerant of highly distinct subcultures. For the liberal who values individual choice, as for the communitarian who purports not to select among visions of the good, it seems odd to afford substantial protection to communities furthest from the majority culture $^{18}$ while affording little protection to those only marginally different from the majority. There seems something anomalous about arguing for protection of groups such as orthodox Jews ${ }^{19}$ or the Amish ${ }^{20}$ when their cultures conflict with majoritarian norms while opposing similar license for those who seek residence in artificially pastoral settings free from technologies that they deem unsightly or who live in such fear of crime that they literally wall themselves off from the outside world. ${ }^{21}$ I am not

16 See, for example, Alexander, 75 Cornell $\mathrm{L}$ Rev at 52 (cited in note 13) ("Communities by their very nature exclude.").

${ }^{17}$ I take the phrase from Judith N. Shklar, Ordinary Vices (Belknap, 1984), to indicate that the bases for exclusion are neither heinous nor exceptional, but the result of common-if objectionable-conduct.

${ }^{18}$ See Symposium: Preservation of Minority Cultures, 25 U Mich J L Ref 539 (1992).

19 See Board of Education v Grumet, 114 S Ct 2481 (1994) (creation of school district along religious lines violates Establishment Clause); American Civil Liberties Union $v$ Long Branch, 670 F Supp 1293 (D NJ 1987) (construction of an "eruv" by religious Jews on city property did not violate Establishment Clause); Smith v Community Board No. 14, 491 NYS2d 584 (NY Sup Ct 1985) (same).

${ }_{20}$ See Yoder, 406 US 205.

${ }^{21}$ See Government by the Nice, for the Nice, The Economist 25 (July 25, 1992); Ann 
certain what underlies this greater affection for the distant than for the proximate. ${ }^{22}$ Since many of the protected groups claim religious or ethnic affiliations, some, but not all, of the explanation may lie in a general concern about discrimination based on religion or ethnicity. I do not point out this puzzle because my argument about associations demands that we accommodate minor deviations from majoritarian norms as readily as we do more divergent subcultures. Instead, I want only to point out that there is nothing unique or obviously implausible to claims that associations should enjoy a level of autonomy based only on the desire of their members to achieve their common view of the good life.

Part I of this Article explains some basic features of association structure and decision making. I also offer some explanations of why individuals may seek refuge in rule making by associations rather than exclusively by traditional governments. That discussion suggests various functions that associations perform and the role of covenants in fulfilling those functions. The variety of functions indicates that there is no monolithic explanation for associations or the covenants that define them. The role of covenants may vary from association to association and from individual to individual within the same association. The common theme that pervades all these institutions is that associations (largely through the drafting and enforcement of covenants) provide some value that traditional governments

Mariano, Enclosed Communities: Havens, or Worse?, Wash Post E1 (Apr 9, 1994).

${ }^{22}$ Mary Anne Case has suggested to me that this phenomenon may be analyzed in terms of the Freudian notion of the "narcissism of minor differences." The smallness of the differences may bring into stark relief the possibility of doing things in a different way or may allow a group to cohere around the way in which it does things by criticizing those who act differently. See Mary Anne Case, Couples and Coupling in the Public Sphere: A Comment on the Legal History of Litigating for Lesbian and Gay Rights, 79 Va L Rev $1643,1662-63$ (1993).

In their contribution to this Special Issue, Christopher Eisgruber and Lawrence Sager implicitly offer a possible solution to this puzzle. Unpopular religious minorities, in their view, are entitled to protection but not privilege. Those closest to the majoritarian norm, however, would presumably not incur the wrath of unpopularity that is visited on distant minorities. Thus, those who are closest to the majority do not require protection. This explanation, while perhaps providing a grounding for constitutional doctrine concerning the relationship between religion and the state, does not provide a complete response to my puzzle insofar as constitutional doctrine does not offer protection to all divergent groups, but only to "religious" ones. Of course, divergent groups do not, by that feature alone, induce calls for protection. We might believe that the American Nazi Party deserves less protection than the Young Republicans, although the former is further from majoritarian norms than the latter. 
cannot, whether it be a good or service, an opportunity for private rulemaking, or assurances of stability.

In Part II, I then inquire into whether those objectives are more likely to be satisfied if we allow associations to administer regulations essentially free of judicial intervention, or if intervention is necessary in the same way that we allow courts to review the decisions of localities. Finally, in Part III, I consider the extent to which judicial intervention is necessary to restrict association activities that affect nonresidents. This last inquiry returns us to the point with which I began, the relationship between communities and the larger society, and offers some thoughts about the circumstances under which we should protect community idiosyncracies, notwithstanding their adverse effects on nonmembers.

\section{The Promise of Residential Associations}

\section{A. The Structure of Residential Associations}

Residential associations range from condominium, cooperative, or homeowners associations with fewer than ten residents to city-sized developments with tens of thousands of residents. ${ }^{23}$ While cooperative and condominium associations share most of the features of homeowners associations that I discuss, ${ }^{24}$ these associations are most like local governments in that they encompass significant geographical areas rather than a single building or series of buildings. ${ }^{25}$ Like municipalities, associations frequently hold property in common for their resident members, and either provide or contract out for the provision of services that benefit members. Associations supply goods and services ranging from the most common municipal functions, such as security patrols and street maintenance, to more exotic but still common municipal services, such as maintaining golf courses or community centers. Like municipalities, associations have the authority to

${ }^{23}$ See ACIR Report at 3 (cited in note 1).

24 Condominium associations typically govern single buildings, whose residents own their residences individually and their common areas (such as hallways and dividing walls) in common. Cooperative associations own and maintain their buildings, while residents own shares in the corporation and have a leasehold interest in their residence. Homeowners associations typically consist of residents who own separate plats and improvements within a development, while the association owns and manages common property such as lakes, streets, and gateways. See, for example, Dilger, Neighborhood Politics at 16-17 (cited in note 1).

${ }^{25}$ For the remainder of this Article, any reference to "association" means homeowners association, unless the context indicates otherwise. 
impose exactions on residents (annual dues or assessments for the maintenance of association property) and to enforce that power by imposing liens on the property of nonpayors. ${ }^{26}$

This is not to suggest that all associations offer the same services. ${ }^{27}$ Indeed, it is partly through the selection of public goods and services that associations foster individual identities. Just as municipalities may distinguish themselves by offering superior schools, spacious parks, or proximity to workplaces, so may associations offer singular services such as security gateways, a golf course, or a "Caribbean Island" motif." 28 But also like municipalities, which may pass ordinances affecting zoning, condominium conversion, or other aspects of residents' welfare, associations assume distinct identities through the regulation of residents. It is through the enforcement of these regulations that legal disputes about the scope of association autonomy are most likely to arise.

Regulation by an association typically takes the form of conditions, covenants, and restrictions (which I will refer to collectively as "covenants") that constitute servitudes imposed on the lots within the association's boundaries. The covenants are initially drafted by the developer of the area before individual units are sold to the public. ${ }^{29}$ In addition, it is routine for voting control over amendment or enforcement of covenants to remain with the developer until a certain number or percentage of units within the development are sold..$^{30}$ At that point, the developer transfers control to the association, or more specifically, to its board of directors. The developer will also create the governance structure of the association by drafting bylaws or articles of incorporation that allocate voting rights within the association and that typically delegate interpretive and enforcement authority over covenants to the board..$^{31}$

${ }^{26}$ See, for example, Westwood Homeowners Ass'n v Lane County, 118 Or App 310, 847 P2d 862, 865 (1993); Board of Directors of Olde Salem Homeowners' Ass'n v Secretary of Veterans Affairs, 216 Ill App 3d 281, 589 NE2d 761, 766 (1992); Inwood North Homeowners' Ass'n v Harris, 736 SW2d 632, 636-37 (Tex 1987).

${ }^{27}$ See Dilger, Neighborhood Politics at 20-23 (cited in note 1) (listing services commonly provided by associations).

${ }_{23}$ See Northern Palm Beach County Water Control District v Florida, 604 S2d 440, 444 (Fla 1992) (Shaw dissenting).

29 See Dilger, Neighborhood Politics at 14 (cited in note 1); Urban Land Institute and the Community Associations Institute, Creating a Community Association: The Developer's Role in Condominium and Homeowner Associations (1977) (on file with the U Chi L Rev).

30 For discussion of voting rights within associations, see Robert C. Ellickson, Cities and Homeowners Associations, $130 \mathrm{U} \mathrm{Pa} \mathrm{L}$ Rev 1519, 1543-44 (1982); Gerald E. Frug, Cities and Homeowners Associations: A Reply, $130 \mathrm{U}$ Pa L Rev 1589, 1592-96 (1982).

${ }^{31}$ See, for example, Robert G. Natelson, Consent, Coercion, and "Reasonableness" in 
Regulatory covenants may be quite lengthy and detailed. They typically purport to regulate such issues as architectural design, ${ }^{32}$ fencing ${ }^{33}$ use of structures, ${ }^{34}$ use of common property ${ }^{35}$ and subdivision of lots. ${ }^{36}$ They may restrict the activities of residents far more than would be expected as a matter of common law or by local ordinance. ${ }^{37}$ Although they no longer control the ethnicity of residents, ${ }^{38}$ covenants may regulate at a microlevel, so that they address such issues as the kinds of pets

Private Law: The Special Case of the Property Owners Association, 51 Ohio St L J 41, 47 (1990).

${ }_{32}$ See, for example, Lookout Mountain Paradise Hills Homeowners' Ass'n v Viewpoint Associates, 867 P2d 70 (Colo App 1993); Davis v Huey, 620 SW2d 561 (Tex 1981); Catalina Square Improvement Committee v Metz, 630 SW2d 324 (Tex App 1982).

${ }_{33}$ See, for example, Black v Fox Hills North Community Ass'n, Inc., 90 Md App 75, 599 A2d 1228 (1992); Prestwick Landowners' Ass'n v Underhill, 69 Ohio App 2d 45, 429 NE2d 1191 (1980).

${ }^{34}$ See, for example, Mains Farm Homeowners Ass'n $v$ Worthington, 121 Wash 2d 810, 854 P2d 1072 (1993) (restriction to single-family residence); Double D Manor, Inc. $v$ Evergreen Meadows Homeowners' Ass'n, 773 P2d 1046 (Colo 1989) (same).

${ }_{35}$ See, for example, MaJor $v$ Miraverde Homeowners Ass'n, 7 Cal App 4th 618, 9 Cal Rptr 2d 237 (1992) (enjoining enforcement of a rule limiting access to recreational areas by nonresident owners).

${ }^{36}$ In condominium association declarations, the association may retain the power to approve the transfer of any interest in a unit. See, for example, Aquarian Foundation, Inc. $v$ Sholom House, Inc., 448 S2d 1166 (Fla App 1984).

${ }^{37}$ See, for example, Murphy v Timber Trace Ass'n, 779 SW2d 603, 607-08 (Mo App 1989) (upholding sign restrictions in covenants although the same restrictions could not have been imposed by a governmental entity); Ellickson, $130 \mathrm{U} \mathrm{Pa} \mathrm{L} \mathrm{Rev} \mathrm{at} \mathrm{1519,} 1528$ (cited in note 30). Compare City of Ladue v Gilleo, 114 S Ct 2038 (1994).

${ }^{38}$ Indeed, many covenants currently include express nondiscrimination clauses. See, for example, Statement of Restrictions Covenants and Conditions for Ivy Farm, Albemarle County, Virginia, which includes the following provision:

Any person, when he becomes an Owner, agrees that neither he nor any one authorized to act for him will refuse to sell or rent, after the making up [sic] of a bona fide offer, or refuse to negotiate for the sale or rental of, or to otherwise make unavailable or deny any of the property owned by him in Ivy Farm to any person because of race, color, religion, sex or national origin.

(on file with the U Chi L Rev).

In Shelley $v$ Kraemer, 334 US 1 (1948), the Supreme Court determined that judicial enforcement of a restrictive racial covenant would constitute state action for purposes of the Fourteenth Amendment. Courts have been reluctant to extend that logic to other areas. See, for example, Linn Valley Lakes Property Owners Ass'n v Brockway, 250 Kan 169, 824 P2d 948 (1992) (holding that enforcement of a restrictive covenant prohibiting the placement of signs on private property is not state action prohibited by the First Amendment); McGuire $v$ Bell, 297 Ark 282, 761 SW2d 904, 911 (1988) (refusing to consider an equal protection argument against the enforcement of a restrictive covenant to prohibit the use of a residence for the mentally disabled). But see Park Redlands Covenant Control Committee v Simon, 181 Cal App 3d 87, 226 Cal Rptr 199, 205-06 (1986) (finding state action where city building permits had been conditioned on certain age and occupancy restrictions). 
that can be kept within the association, numbers of guests that can be accommodated, the erection of a satellite dish, ${ }^{39}$ the size of a mailbox ${ }^{40}$ exterior colors, ${ }^{41}$ and types of vehicles maintained on the premises. ${ }^{42}$ In short, it is largely through the explication and enforcement of these covenants that the association signals its vision of the good life to current and prospective homeowners.

Even for those within the association, covenants, which are intended to bind current owners and their successors for decades, necessarily contain ambiguities. ${ }^{43}$ The passage of time can only exacerbate these ambiguities as technologies develop and social norms change. ${ }^{44}$ The original purposes for restrictions on fencing, perhaps intended to ensure unimpaired vistas, may have little application to electronically controlled "invisible" fencing that keeps pets from wandering; limitations on uses to "singlefamily" residences may have uncertain application in an age when group homes challenge traditional concepts of what it means to be a "family." Efforts to resolve these ambiguities have caused both courts and commentators difficulty in determining how rigorously and by what standard to review the application of association covenants.

One approach has been to incorporate rules drawn from seemingly analogous areas. Most commonly, covenants are sub-

${ }^{39}$ See, for example, Miller v First Colony Community Services Ass'n, 1993 Tex App LEXIS 2443.

40 One covenant for Rosemont, a subdivision within Albemarle County, Virginia, provides:

Section 8.05. Mail Boxes. The [Architectural Control Board ("ACB")] shall provide a description and/or sketch of what is permissible for mail boxes and/or paper delivery boxes. No mail or paper delivery boxes deviating from that so specified by the ACB shall be erected without the prior written approval of the ACB as to location, color, size, design, lettering and all other particulars of such mail or paper delivery boxes, and the standards, brackets and name signs for such boxes.

(on file with U Chi L Rev). 1956).

"1 See, for example, West Hill Colony, Inc. $v$ Sauerwein, 138 NE2d 403 (Ohio App

12 See, for example, Cottrell v Miskove, 605 S2d 572 (Fla Dist App 1992); Forest Glen Community Homeowners Ass'n v Nolan, 104 Ill App 3d 108, 432 NE2d 636 (1982).

${ }^{13}$ See Robert D. Brussack, Group Homes, Families, and Meaning in the Law of Subdivision Covenants, 16 Ga L Rev 33, 34-40 (1981).

4 The passage of time may also lead to a problem of obsolescence for some covenants. See Glen O. Robinson, Explaining Contingent Rights: The Puzzle of "Obsolete" Covenants, 91 Colum L Rev 546 (1991). My concern here is more with ambiguity than with obsolescence, although to the degree that courts would ultimately determine whether a covenant has become obsolete, the same analysis about the proper scope of judicial intervention would apply. 
sumed within the law of servitudes, even though covenants governing many associational concerns will have difficulty satisfying the technical requirements of servitude law, such as the prerequisite to enforcement that the servitude "touch and concern" the land. ${ }^{45}$ Incorporating these covenants within traditional servitude law loads the dice against the party seeking enforcement of the covenant; property law has a long history of disfavoring restraints on alienation. ${ }^{46}$ The legal doctrine that has evolved from this disfavor insists on strict construction against limitations on the contested use. ${ }^{47}$ In myriad rulings on association covenants, courts explicitly invoke the rule of strict construction with reference to little other than historical disapproval. ${ }^{48}$

Other courts, and several commentators, rely on the contractual nature of association membership to justify a different approach. ${ }^{49}$ They purport to invoke the intent of the parties, ${ }^{50}$ or the volitional nature of the undertaking, ${ }^{51}$ in spite of evidence that association residents tend to be ignorant of the covenants by which they are governed..$^{52}$ Hence, much of the debate about the

${ }^{45}$ See Mountain Park Homeowners Ass'n v Tydings, 864 P2d 392, 395 (Wash App 1993); Lookout Mountain Paradise Hills Homeowners' Ass'n v Viewpoint Associates, 867 P2d 70, 74 (Colo App 1993); Natelson, 51 Ohio St L J at 50-51 (cited in note 31); Uriel Reichman, Judicial Supervision of Servitudes, 7 J Legal Stud 139 (1978).

${ }^{46}$ See James L. Winokur, The Mixed Blessings of Promissory Servitudes: Toward Optimizing Economic Utility, Individual Liberty, and Personal Identity, 1989 Wis L Rev 1, 7-16. Winokur suggests that courts took a still less charitable view of servitudes before the nineteenth century, when economic development suggested a need for controls on private land use.

${ }^{47}$ See Ritchie v Carriage Oaks Homeowners Ass'n, 592 S2d 361 (Fla Dist App 1992); Woodcreek Ass'n v Bingle, 73 Ohio App 3d 506, 597 NE2d 1153, 1156 (1991); Barber v Dixon, 302 SE2d 915, 916-17 (NC App 1983); Wisneiwski v Starr, 393 S2d 488, 489 (Ala 1980); Wayne S. Hyatt, The Community Association: An Introduction, C500 ALI-ABA 363, 366 (1990).

48 See, for example, Lathan v Hanover Woods Homeowners Ass'n, 547 S2d 319 (Fla App 1989); Lake St. Louis Community Ass'n v Leidy, 672 SW2d 381 (Mo App 1984).

49 See, for example, Richard A. Epstein, Notice and Freedom of Contract in the Law of Servitudes, 55 S Cal L Rev 1353, 1353 (1982); Uriel Reichman, Residential Private Governments: An Introductory Survey, 43 U Chi L Rev 253, 279-83 (1976); Reichman, 7 J Legal Stud at 154; Ellickson, $130 \mathrm{U} \mathrm{Pa}$ L Rev at 1526-30 (cited in note 30).

${ }^{50}$ See Arizona Biltmore Estates Ass'n v Tezak, 868 P2d 1030 (Ariz App 1993); Norwood-Norland Homeowners' Ass'n v Dade County, 511 S2d 1009, 1014 (Fla App 1987); Gigowski v Russell, 718 SW2d 16, 18 (Tex App 1986).

${ }^{51}$ See, for example, West Hill Colony, Inc. $v$ Sauerwein, 138 NE2d 403, 405 (Ohio App 1956).

${ }^{52}$ See Dilger, Neighborhood Politics at 35 (cited in note 1); Winokur, 1989 Wis L Rev at 59-60 (cited in note 46). It is difficult to know what to make of the question of purchaser ignorance, both as a descriptive and a normative matter. Several states have recently required disclosure of association covenants to prospective purchasers, so that knowledge may increase with time. See, for example, Fla Stat Ann $\$ 718.503$ (West 1988 \& Supp 1994); Mont Code Ann § 70-23-613 (1993); Va Code § 55-511 (Supp 1993); Wis Stat Ann § 
enforcement of covenants simply reflects broader debates about the scope and meaning of freedom of contract. Landlord-tenant law, ${ }^{53}$ local government law, ${ }^{54}$ and the law of private corporations $^{55}$ have also been impressed into service to explain the scope of association decision making and the proper scope of judicial review. In addition, regardless of the specific analogy used, courts frequently examine the "reasonableness" of the restriction and its application. ${ }^{56}$ Commentators have found this reasonableness test to be more stringent than the test that courts apply to the regulations imposed by the entities to which associations are compared. ${ }^{57}$

While these analogies provide some context by which to measure the role and autonomy of associations, none of them reaches the issue most relevant to judicial intervention into associations'

703.33 (West 1981 \& Supp 1993). Natelson attributes an increase in condominium-owner knowledge to the existence of such statutes and to possible causes of action for rescission where disclosure was not made. Natelson, 51 Ohio St $\mathrm{L} J$ at 62 (cited in note 31 ).

The question of how much information a purchaser must have before he or she has "consented" to the terms of the purchase is much debated in the literature. I believe that" this question, like the question of consent in any other purchase, is best answered by asking whether we believe that one of the parties is systematically disadvantaged in a manner that mandates intervention by a third party (typically a court) to undo the transaction. Traditionally, this would require more than mere ignorance; it would require that the party claiming disadvantage did not have the knowledge, and could not reasonably have obtained an opportunity to secure it.

${ }_{53}$ See Frances T. $v$ Village Green Owners Ass'n, 42 Cal 3d 490, 723 P2d 573, 576 (1986).

54 See Cohen v Kite Hill Community Ass'n, 142 Cal App 3d 642, 191 Cal Rptr 209, 214 (1983); Katharine Rosenberry, Condominium and Homeowner Associations: Should They be Treated Like “Mini-Governments?", in ACIR Report at 69 (cited in note 1).

ss See Vernon Bowdish Builder, Inc. v Spalding Lake Homeowners' Ass'n, 196 Ga App 370, 396 SE2d 24 (1990); Beehan v Lido Isle Community Ass'n, 70 Cal App 3d 858, 137 Cal Rptr 528, 531-32 (1977); Jeffrey A. Goldberg, Community Association Use Restrictions: Applying the Business Judgment Doctrine, 64 Chi Kent L Rev 653, 664-69 (1988).

s8 See, for example, Annis v Turtle Creek Homeowners Ass'n, 1992 Neb App LEXIS, *9; Holiday Pines Property Owners Ass'n $v$ Wetherington, 596 S2d 84, 87 (Fla App 1992); Oakbrook Civic Ass'n v Sonnier, 481 S2d 1008 (La 1986). The "reasonableness" standard is often embodied in statute. See Cal Civil Code $\$ 1354$ (a) (West Supp 1994) ("The covenants and restrictions in the declaration shall be enforceable equitable servitudes, unless unreasonable . . . ."); Note, Judicial Review of Condominium Rulemaking, 94 Harv L Rev 647, $652 \mathrm{n} 29$ (1981). Some courts, however, specifically eschew investigation into the reasonableness of a regulation. In Hidden Harbour Estates, Inc. $v$ Basso, 393 S2d 637, 640 (Fla App 1981), the court declared that use restrictions in a declaration of a condominium may have "a certain degree of unreasonableness" but still be judicially upheld. Professor Ellickson asserts that reasonableness review is appropriate with respect to amendments to covenants, though not with respect to the original covenants. See Ellickson, $130 \mathrm{U} \mathrm{Pa} \mathrm{L}$ Rev at 1526 (cited in note 30 ).

${ }^{67}$ See Jesse Dukeminier and James E. Krier, Property 935 (Little, Brown, 3d ed 1993). 
affairs: the core question of institutional competence. The level of associations' autonomy to govern the relationships among their members or between members and nonmembers should depend on the threshold questions of what roles associations play and the extent to which, left to their own devices, covenants will fulfill those roles. It is to these threshold questions that I next turn.

\section{B. Models of Residential Associations}

1. The public goods model.

a) Associations as providers. For those who consider a primary value of local governments to be their capacity to provide local public goods efficiently, the ability of residential associations to achieve that same objective underlies much of their appeal. Local public goods are susceptible to misallocation for a variety of reasons. Most obviously, a locality's boundaries may not coincide with the ideal service area for a good or service that the locality provides. This follows from the fact that local public goods tend to be impure. Over some range, they exhibit the nonrivalness and nonexcludability characteristics of public goods. Were that not the case, there would be little reason to rely on collective provision, rather than market mechanisms, to make the good available at all. The range over which a good displays these characteristics, however, may be larger or smaller than the locality as a whole. Because localities provide an array of goods and services, it is unlikely that any one of them will fit perfectly within municipal boundaries. Ideal areas for police services, for instance, may have little to do with the ideal areas for water service or schools.

This lack of fit may lead a state or its localities to offer a particular service through a more centralized entity, a fact that explains the attractiveness of special districts or metropolitan organizations. ${ }^{58}$ But the lack of coincidence between municipal boundaries and ideal service areas may also compel further decentralization, since local governments may otherwise be unable either to measure accurately the demand for the service within the locality or to provide the service to those who value it most highly. A primary source of this inability is the divergent preferences of municipal residents. In the absence of highly styl-

58 See, for example, Comment, An Analysis of Authorities: Traditional and Multicounty, 71 Mich L Rev 1376, 1426-27 (1973); Advisory Commission on Intergovernmental Relations, Metropolitan Organization: The Allegheny County Case 86-88 (1992). 
ized assumptions concerning mobility, numbers of localities, and consumer information, all residents of a locality will not share the same tastes for all municipal services. ${ }^{59}$ The result may be that residents within the locality have very different views about what local public goods and services should be provided, and in what amounts.

Provision in accordance with the community's median preferences may be frustrated by the ability of discrete majorities or privileged minorities to form and impose their own tastes on others who neither desire the good nor can take advantage of it, but who also cannot effectively lobby against its public provision or escape payment for it. Escape will be frustrated where the price of the good is bundled-through taxes-with the price of desired goods. Those who favor a municipally financed golf course, for instance, may successfully lobby for its creation, even though (1) the spillover benefits to nonusers are minimal, (2) nonusers represent a substantial segment of the population, and (3) those who favor the golf course would be unwilling to incur the entire cost themselves if they could not impose some of the cost on other residents. If a measure to construct the golf course passes, those who oppose it and who do not benefit from it will be unable to avoid subsidizing the project if financing is procured through property taxes that all residents must pay. As a result, localities will tend to overspend on goods that are not desired by all constituents and that are only impurely "public" throughout the locality. ${ }^{60}$

A discrete group that prefers a good not desired (or more of a good than is desired) by others within the community, however, will be successful in obtaining it only if the group can secure the support of the local decision-making body. Legal doctrine as well as political concerns usually mean that the group faces an uphill battle. Localities are bound by legal obligations of equal service $^{61}$ and "public purpose" spending ${ }^{62}$ that are imposed to pre-

59 See Tiebout, $64 \mathrm{~J} \mathrm{Pol} \mathrm{Econ} \mathrm{at} 426$ (cited in note 8). In creating his model for an ideal allocation of public services, Tiebout assumed that under certain conditions, including perfect mobility, information, the absence of externalities, and choice among substantial numbers of localities, individuals with similar preferences would migrate to the same locality, so that those within a given locality would share the same preferences. Where those assumptions fail, however, individuals with different preferences will share the same locality.

${ }^{60}$ See, for example, James M. Buchanan and Gordon Tullock, The Calculus of Consent 135-45 (Michigan, 1962) (road paving problem); Henry J. Raimondo, Economics of State and Local Government 77-79 (Praeger, 1992).

61 Veach v Phoenix, 102 Ariz 195, 427 P2d 335, 337 (1967).

62 The public purpose doctrine requires that municipal expenditures benefit the entire 
vent invidious discrimination within the municipality or to preclude discrete groups from lobbying successfully for unique benefits. ${ }^{63}$ As one result of these doctrines, even where the effects of public provision coincide with local boundaries, localities cannot readily respond to differential demand by residents. Residents within the locality who would prefer to trade one service for another are unable to do so. For example, a locality that provides more police services to one neighborhood than another will likely face claims of unequal service provision and will have difficulty claiming that it has compensated for the disparity by providing more of a different service in the area underserved by police. Even a group that desires unique services and that can overcome these doctrinal difficulties in securing its agenda will face obstacles because traditional free-riding problems induce rational residents to eschew participation in the effort to secure desired services. Those who prefer the service may be difficult to identify or to monitor, especially where they are spread throughout the locality.

Thus, residents who desire a service not preferred by a majority within the locality may be better off if they can bind themselves to pay for the service through private funds. Associations provide just such an opportunity for those with similar preferences to gravitate to a common area and bind each other to make payments for the goods that they find most attractive, but that cannot be easily obtained through political processes. It is important to note, since I will return to this theme, that those joining the association thereby evince a desire for private ordering rather than for politics. At the same time, provision of the service by the association may be socially desirable, since it reduces the incentives of the group to seek subsidies through the public treasury for goods and services that the majority would prefer not to provide. In these circumstances, the further decentralization of provision requires those who idiosyncratically prefer a different good or more of a good than the majority to pay something closer to its full cost. Individuals who, for instance, desire more police services than the average resident of the municipality may find it easier to coalesce in a section of the municipality and hire private

locality rather than one segment of it. See Anderson $v$ Baehr, 217 SE2d 43, 47 (SC 1975); Robert S. Amdursky and Clayton P. Gillette, Municipal Debt Finance Law §§ 3.1, 3.5 (Little, Brown, 1992).

${ }_{63}$ See Ammons $v$ Dade City, 783 F2d 982 (11th Cir 1986); Dowdell v City of Apopka, 698 F2d 1181 (11th Cir 1983). 
security forces rather than to lobby for more police services citywide. ${ }^{64}$ The result of all these phenomena is that residential associations hold out the promise that services can be more directly linked to the tastes of particular residents. By matching more precisely the supply and demand of public goods, associations play much the same role that municipalities seek to accomplish by privatizing local services or by shifting to user fee schemes to pay for publicly provided services. ${ }^{65}$

Associations may also solve the allocational problems that can arise even if a local public good has a benefit range consistent with municipal boundaries. A public good may be subject to congestion if the entire public is able to use it. Again, the golf course serves as an example. Within a segment of the locality, the demand for the golf course may be sufficiently small that it takes on the nonrival features of a public good; once open to the entire locality, however, congestion and the concomitant need for size restrictions become apparent. ${ }^{66}$ Providing the good to members of a restrictive "club" creates a pattern of provision consistent with actual preferences; those who pay for the golf course will be able to enjoy its full use, not a use limited and devalued by congestion.

Once more, associations allow those who share preferences to create a system that restricts access and thereby makes an asset more useful. At the same time, the binding nature of the association's covenants that obligate members to pay for the asset overcomes holdout problems and transaction costs that would likely frustrate efforts to restrict access through a series of explicit contracts. ${ }^{67}$ While we might be justifiably concerned with some grounds for restriction, for the moment I am concerned only with establishing the principle that restrictions on access by a club are not inherently suspect, and may be essential to ensure optimal use of a resource.

This optimistic story about the allocational benefits of decentralization, however, may be offset by distributional effects of

64 See Ronald J. Oakerson, Private Street Associations in St. Louis County: Subdivisions as Service Providers, in ACIR Report at 55, 57-59 (cited in note 1).

65 For a discussion of the ways in which user fees may coordinate the provision of public services and the willingness to pay for them, see Clayton P. Gillette and Thomas D. Hopkins, Federal User Fees: A Legal and Economic Analysis, 67 BU L Rev 795 (1987).

${ }_{66}$ See Todd Sandler and John T. Tschirhart, The Economic Theory of Clubs: An Evaluative Survey, $18 \mathrm{~J}$ Econ Lit 1481, 1482 (1980).

${ }_{67}$ For defense of covenants based on avoidance of holdout problems, see Richard A. Epstein, Covenants and Constitutions, 73 Cornell L Rev 906, 921-22 (1988). 
allowing residents to pick and choose municipal services. The pessimistic story is that municipal residents who can afford to do so will isolate themselves in associations where they can contract privately for desired services and oppose additional municipal funding of the same services for outsiders. For instance, those who seek above-average levels of security and can afford to do so will take refuge in privately patrolled enclaves and then oppose significant funding of municipal police services in order to minimize their total of tax payments and private payments. To the extent that private deterrents do not reduce crime, but only redirect it, allowing private funding of police services not only invites underfunding for outsiders, but also imposes disproportionate amounts of crime on those who are not association members.

Although the pessimistic story may accurately describe some consequences of association autonomy, the issue of who is imposing undesirable activities on whom is more complicated. Even assuming that we wish to address questions of redistribution at a decentralized level, ${ }^{68}$ some checks exist on the willingness or ability of association members to reduce benefits to others. Residents who provide their own services might still wish to maintain property values throughout the locality in order to support their own values, and hence support a high level of services throughout the locality. Think, for instance, of whether those who send their children to private school would necessarily oppose increases in public school funding. The desire to maintain resale values of their homes might lead even those who do not directly use public schools to contribute to quality education in the community. Further, those within the association are likely to view the question of external effects in a different light. Association members are likely, for instance, to consider crimes committed within the association by nonmembers as externalities imposed by the rest of the community on them. There seems little basis for an ethical claim that they should be disabled from taking protective measures that reduce these externalities, whether those measures entail the purchase of expensive locks, neighborly agreements to watch each other's homes, contractual agreements between a homeowner and a private security firm, or contractual

68 There is a substantial literature that suggests that redistributional issues are not well addressed at the local level, because of opportunities for exit by those who are best off and not altruistic. See, for example, Helen F. Ladd and Fred C. Doolittle, Which Level of Government Should Assist the Poor?, 35 Natl Tax J 323 (1982); Ellickson, 130 U Pa L Rev at 1554-56 (cited in note 30). 
agreements by an association on behalf of numerous homeowners and the same security firm. Indeed, given the signalling role that we often attribute to individual choices, it seems odd to suggest that we might prohibit those dissatisfied with municipal services from obtaining a different level of services from another provider. Just as customer exit from a firm's product indicates a competitive failure, if substantial numbers of residents opt out of a municipal service, we typically think we have received important evidence that local officials have misunderstood the preferences of residents. ${ }^{69}$ It would be difficult to bar residents from acting on their distinct preferences for a particular level of service without simultaneously hindering residents' ability to signal their dissatisfaction to their officials.

Finally, private provision of services may actually have a positive distributional effect on nonmembers. Members who make payments to associations for services that would otherwise be provided in whole or in part by the locality are typically not permitted to offset those payments against local taxes. The locality, therefore, can either reduce tax payments for all residents or expend additional funds for locality-wide services. ${ }^{70}$ In either case, payments for private services that reduce the need for municipal services within the association increase the ability of the locality to address the needs of nonmember residents.

The distributional effects of associations and the justifications for them, therefore, are more ambiguous than might be thought from simplistic initial reactions that view these entities either as mechanisms of escape for the privileged or as social benefactors that limit wasteful cross-subsidies. I will return to the distributional issue both in discussing the role of covenants and, in the last part of this Article, in analyzing when the external effects of covenants may be so significant as to warrant judicial intervention. For the moment, I conclude only that facile responses to the issue are unsuitable.

69 See Albert O. Hirschman, Exit, Voice, and Loyalty 16-17 (Harvard, 1970).

70 See, for example, ACIR Report at 18 (cited in note 1). The positive redistributional effects would disappear if residents of associations received some rebate on their tax payments for the costs of privately provided services; although, as the text indicates, this is not the typical situation. New Jersey requires municipalities either to provide certain services to a "qualified private community," such as a homeowners association, or to reimburse a "qualified private community" that provides its own services. Services covered by the requirement include street maintenance, street lighting, and refuse collection. See NJ Rev Stat $\S \S 40: 67-23.2$ to 23.8 (1993). 
b) Covenants as proxy and as common plan. Even if we accept that associations can play a substantial role in matching service preferences and payments, it is not obvious that association covenants are necessary to accomplish that objective. Covenants other than those relating to payment obligations ${ }^{71}$ rarely address issues of service, and the legal disputes that construe association covenants are seldom directly related to service provision. Instead, the cases, at least those that are reported at the appellate level, tend to be concerned with maintaining prohibited structures or land uses or acting in a manner that offends the aesthetic tastes of other members. ${ }^{72}$ Hence, one might conclude that the goal of providing an optimal level of public goods within the association has few implications for the interpretation of the association's covenants.

On reflection, however, the relationship between covenants and services may be more substantial. As noted above, the goods that associations provide tend to be impure public goods beyond a limited geographical range. At some point, congestion will threaten the ability to take advantage of roads, lakes, golf courses, or other common areas typically administered by localities or associations. ${ }^{73}$ Hence, some sorting mechanism is necessary to separate those who are and are not entitled to the good. Explicit pricing, first come/first served, or auctions may all be used for such separation; association covenants provide an alternative: selection on the basis of homogeneity. ${ }^{74}$ While we do not necessarily value homogeneity where it is based on invidious forms of discrimination, association covenants (at least those that courts will be willing to enforce $)^{75}$ typically discriminate on more mundane characteristics of lifestyle. Covenants that indicate socially acceptable, if not universally commended, lifestyles permit individuals who seek to live among those with similar $\operatorname{tastes}^{76}$ a rela-

7 See, for example, Regency Homes Ass'n $v$ Egermayer, 243 Neb 286, 498 NW2d 783 (1993) (foreclosure of lien for failure to pay dues to maintain recreational facilities); Lake Arrowhead Community Club, Inc. v Looney, 112 Wash 2d 288, 770 P2d 1046 (1989) (enforcement of covenant to pay assessments for neighborhood facilities); Inwood North Homeowners' Ass'n v Harris, 736 SW2d 632 (Tex 1987) (enforcement of covenant to pay assessments for repair of common areas); Jeffrey E. Stake, Toward an Economic Understanding of Touch and Concern, 1988 Duke L J 925, 961-64.

${ }^{72}$ See cases cited in notes $32-42$.

73 See Todd Sandler, Collective Action 63-65 (Michigan, 1992).

74 See Sandler and Tschirhart, $18 \mathrm{~J}$ Econ Lit at 1482 (cited in note 66).

${ }_{75}$ Covenants that violate constitutional or statutory provisions will not be enforced. See Shelley $v$ Kraemer, 334 US 1 (1948); Taormina Theosophical Community, Inc. v Silver, 140 Cal App 3d 964, 190 Cal Rptr 38 (1983).

${ }^{76}$ On the frequency and propriety of such motivations, see Thomas C. Schelling, 
tively costless means of identifying each other. At the same time, covenants allow individuals to define characteristics of the favored lifestyle. As indicated above, lifestyle choices may be reflected in a desire for differential levels of service, such as security; but lifestyles may also be reflected in an aversion to certain activities or land uses to which a segment of the population is uniquely averse. The legal effects that we give to covenants, effectively making them operative in perpetuity, provide the added assurance that homogeneity of preferences will remain. The same stability cannot be attributed to zoning ordinances, which are susceptible to political shifts.

In this way, covenants solve a coordination problem. Individuals who seek a specific package of services may (or may not) also care about the other characteristics of those with whom they share club goods. For those who are indifferent, traditional neighborhoods or associations with few covenants unrelated to service will be appropriate. For others, however, service packages and homogeneity are inherently related. For these groups, covenants provide a salient signal, reducing both the search costs involved in finding like-minded individuals and the risk of regret that would be suffered should one discover, after making an expensive home purchase, that the neighborhood is less hospitable than originally assumed. ${ }^{77}$ For those to whom service packages are secondary to concerns about the externalities imposed by living within the immediate range of particular activities or structures, and who desire more control than can be afforded by zoning or market mechanisms alone, covenants provide both a private means of rulemaking that reflects those desires and a stabilizing precommitment device against changing preferences.

My claim, then, is that covenants may play multiple roles in the allocation of local public goods. They permit individuals whose preferences to encourage or discourage discrete activities are sufficiently common to serve as a coordination point, but not so robust as to warrant supervision by a governmental body, to enact regulations that supplement those of the state. For those who consider any competing lifestyle to be an externality imposed on them, covenants produce a tranquil homogeneity. And for those who seek security in the status quo, covenants also provide

Micromotives and Macrobehavior 137-90 (Norton, 1978); Thomas C. Schelling, Models of Segregation, 59 Am Econ Rev 488 (1969).

77 See Edna Ullmann-Margalit, The Emergence of Norms 104-09 (Oxford, 1977). 
a mechanism that binds both themselves and others against radical change in those desires.

But covenants do not simply regulate the specific activity they address. The preferences that motivate individuals to migrate to a particular location or association may not be readily susceptible to precise description. Covenants may serve as rough, but appropriate, surrogates, providing signals of sufficient salience to allow coordination among individuals with vague, but similar, lifestyle preferences. In this sense, covenants are indicators of a way of life, rather than simply restrictions on specific land uses.

For instance, even where individuals do not have an aversion to certain practices that are prohibited in covenants, such as maintenance of trailer homes, they may believe that there is a correlation between the subject of the covenant and characteristics that can serve as the basis for a desirable affinity. I may have nothing against trailer homes, other things being equal. That is, I may believe that they are not aesthetically displeasing, and may believe that they offer the best available housing opportunities for a large segment of the population. I may, however, simultaneously seek a relatively noise-free environment, or assurances that I live among others who do not mind a high degree of regimentation, and hence are less likely to be offended when I complain of what to me is excessive noise. A covenant against "unreasonable noise" may be too imprecise to accomplish my objectives. I therefore may prefer a more certain surrogate that reflects the level of comfort to which I aspire. If I believe that the presence of trailers is positively correlated with bothersome levels of noise, a covenant against trailer homes may serve this proxy role. Similarly, while few might object to a general standard that neighbors not engage in activities that are "unsightly" or that "diminish property values," the difficulty of agreeing, ex post, on what activities satisfy these criteria might warrant, ex ante, precise restrictions that reduce subsequent costs of deciding whether the community standard has been violated.

More than serving as proxies for less describable characteristics, however, covenants that bar specific activities describe a common plan. A set of covenants taken together may be attractive to some and repugnant to others. For some, the set of covenants may indicate order, belonging, and security. For others, the same set may signal regimentation, exclusion, and elitism. But the very fact that the set of covenants, taken as a whole, can send either signal suggests that covenants have the capacity to 
form a basis of association for those who share a view of the good life. In this sense, homogeneity serves as an appropriate discriminant for ascertaining who is entitled to a club good. As common plans, more than as specific governance structures, covenants form private constitutions; ${ }^{78}$ thus, the judicial role in construing covenants should be debated in light of their implicit constitutive benefits, not merely their formal provisions.

While I believe that these characteristics accurately capture the utility of covenants, I admit to some discomfort about allowing too much to turn on them. Some proxies will either be irrational or will be used too readily as surrogates for discrimination on bases more invidious than I want to endorse. Those who live in trailer homes, for instance, may in fact be no more prone to noisy behavior than others, notwithstanding my irrational view. Alternatively, the ban on trailer homes may serve more as a surrogate for wealth than for noise; it is less clear that we would embrace an explicit exclusion on that basis, even if constitutionally permissible. ${ }^{79}$

Nevertheless, neither irrationality nor prejudice (short of the type that triggers constitutional concerns) necessarily means associations should be condemned or receive greater judicial scrutiny than would otherwise apply. Covenants that are based on irrationality should become obsolete or be repealed without external intervention, since their enforcement would reduce market values for the rational majority of prospective homeowners. In addition, the "rationality" of some reactions, for example, whether satellite dishes are aesthetically displeasing, may be quite subjective. In such cases, there is little reason to convert courts into arbiters of collective rationality.

Covenants that exclude on the basis of common prejudice are more problematic. Recall that part of our ambivalence about decentralization has to do with the tendencies of communities to isolate themselves, to cut themselves off from the problems of the larger society rather than to embrace some idiosyncratic view of the good life. If our reaction to associations is predicated on their tendencies for residential isolation, however, then placing constraints uniquely on these entities seems inappropriate. Isolation or sorting may take many forms other than the creation of homogeneous associations. Established neighborhoods and even com-

${ }^{78}$ See Epstein, 73 Cornell L Rev at 906-07 (cited in note 67).

79 See San Antonio Independent School Dist. v Rodriquez, 411 US 1 (1973) (holding that wealth is not an inherently suspect classification). 
plete towns or cities (certainly suburbs) tend to sort by income or socioeconomic status, even without covenants. Sorting may be assisted by zoning regulations that restrict or invite certain types of housing or individuals with certain incomes. Indeed, some neighborhoods invite sorting into diverse groups by offering a mix of housing alternatives within a relatively small geographical area. Thus, even if we rejected or narrowly construed covenants that had these tendencies, we would not eliminate the sorting that may be attributed to homogeneous associations. One may object, however, that even if we permit this kind of sorting, we need not facilitate the practice by embracing covenants that allow relatively costless patterns of homogeneity. Indeed, the high costs associated with sorting by incorporating a municipality or enacting zoning regulations to codify isolationist preferences might be considered a means by which we ensure that those who sort themselves do so only after considering (and internalizing) some of the social burdens associated with their preferences.

This reaction, however, seems questionable on a number of grounds. Most obviously, sorting that occurs within neighborhoods of a municipality requires fewer, not greater, costs than the formation of an association, although the permanency of covenants means that neighborhoods may be less stable than associations. In addition, if we believe there is something untoward about sorting on these characteristics, then it seems odd to allow them to be embodied by a governmental entity, such as an incorporated municipality, but not by private individuals.

More to the point, however, the attack on homogeneous sorting denies the very condition that seems to underlie the desire for community. If we attribute any positive significance to distinct communities, we are hard pressed to forbid all exclusions that maintain the social cohesion that defines the community. ${ }^{80}$ As Gregory Alexander has written:

80 Professor Frug argues: "Those who want to move to a neighborhood should not face community-imposed obstacles to doing so (the community should have no right to exclude them). But the ability to maintain a relatively homogeneous community should also not be forbidden (there should be no right to be included)." Frug, $60 \mathrm{U}$ Chi L Rev at 291 (cited in note 6). Frug suggests that he can reconcile these two views by forbidding a community to prohibit "outsiders" from moving in, but refusing to force anyone within the community to sell to an outsider. Id at $291 \mathrm{n} 182$. I am more skeptical of this attempt at reconciliation. If the community defines itself by reference to exclusion, then it is unclear why the community cannot enforce its view against its members, especially those (sellers) who are about to move out and thus will not internalize the consequences their sale to an outsider has on the community that remains. 
Precisely because [communities] are constituted by shared commitments to some specific good they must, in symbolic effect if not in conscious intention, exclude some members of the society, precluding those individuals from participating in the group's internal life. ${ }^{81}$

Thus, the fact that some people select residence on the basis of homogeneity while others select on the basis of diversity seems to strengthen rather than threaten the objectives pursued in community's name.

Finally, the concern for the use of covenants as proxies for discrimination on the basis of wealth may make sense against a background in which most associations are seen as weapons of the wealthy. But there are reasons to believe that the same tools may be used by those less advantaged. Recent press accounts indicate that residents of low-income housing units have attempted to bar certain undesirable activities, and those efforts would presumably be simplified if they could be embodied in covenants that bound all tenants. ${ }^{82}$ Given that the distributional issues surrounding covenants are, at best, complicated, courts do not necessarily have any advantage over political processes or housing markets in identifying situations where the community's exclusion becomes inappropriate. And judicial competence is least plausible where a covenant's exclusions rely on bases that do not offend constitutional protections. In Section III, I return to this question in order to identify situations in which courts might refuse to enforce covenants that have substantial effects on nonresidents.

c) Associations as enforcers of covenants. Even where covenants among private actors capture the benefits of homogeneity, stability, and more appropriate levels of service, homeowners associations might still be superfluous. The covenant, not the governing body, gives expression to a common perspective of the good life. The terms of the covenant make violations of this perspective apparent to, and enforceable by, individual residents. Individual enforcement of covenants, however, is costly both in terms of the effort (including financial effort) that must be expended to remedy an alleged violation, and in terms of the injury

81 Alexander, 75 Cornell L Rev at 52 (cited in note 13).

2 See, for example, Jan Crawford, Lane Says He Could Back Voluntary CHA Searches, Chi Trib B1 (Apr 20, 1994). 
to neighborly relations that one must risk by "snitching" on the defector. For any one resident, each of these costs can be avoided if some other resident undertakes the enforcement action. The expected result is that individual residents, even those who object to a violation, will underenforce the community's norm.

There will be cases in which some residents suffer greater harms from a violation than others, and hence have greater enforcement incentives. For instance, the neighbor whose view is directly impaired by the offending fence or color scheme may be more likely to seek redress than the down-the-street resident who primarily fears the inroads that the offense makes on general neighborhood conformity. But because these more noxious harms are likely to result from physical proximity to the violator, the offended neighbor is also more likely to value sociable relations with the violator, and may forgo enforcement to preserve them. Conversely, where violators are distant from those offended, and neighborly relations are thus less important, the noxious activity is likely to have subtler or more diffuse effects, so that any offended neighbor will again have little incentive to enforce.

The same problem hampers the enforcement of community norms against the outside world. Members of a community will typically believe that they should be able to enforce their norms, even where those norms conflict with those of the larger locality. They may, for instance, claim that zoning regulations do not apply within the association's boundaries, or that restrictions that apply to local governments do not apply to private communities. ${ }^{83}$ Yet because all members would enjoy the benefits of testing the proposition, none has an incentive to incur the costs related to asserting the claimed rights.

In all cases that affect the collective rights of association members, whether those members have grievances against the initial developer, against other association members, or against external activity that threatens the autonomy of the group, ${ }^{84}$ the association, as the members' representative, is capable of over-

${ }^{83}$ See, for example, Mains Farm Homeowners Ass' $v$ Worthington, 121 Wash 2d 810, 854 P2d 1072, 1078-79 (1993) (holding a state zoning law is not applicable to association members); Murphy v Timber Trace Ass'n, 779 SW2d 603, 607 (Mo App 1989) (holding an association may ban "for sale" signs even though cities cannot); Vienna Bend Subdivision Homeowners Ass'n v Manning, 459 S2d 1345, 1350 (La App 1984) (concluding that zoning ordinances and restrictive covenants are governed by the same principles).

84 See Shevock v Orchard Homeowners Ass'n, Inc., 621 A2d 346 (Del 1993) (action to enjoin change in zoning ordinance); Gulfport $v$ Wilson, 603 S2d 295 (Miss 1992) (action to enjoin amendment to restrictive covenant); Washington Shores Homeowners' Ass'n v Orlando, $602 \mathrm{~S} 2 \mathrm{~d} 1300$ (Fla 1992) (action to oppose local bond issue). 
coming the obstacles to collective action. ${ }^{85}$ In fact, at least one court has found that a homeowners association could be liable to its members for failure to enforce its covenants. ${ }^{86}$ The presence of the association reduces enforcement costs by creating a repeat player who is charged with monitoring compliance and designating the association as the party who must seek redress. The association's interests may even coincide with those of its nonmember neighbors, each of whom similarly suffers from inducements to free riding, but none of whom has a surrogate similar to the association. In such a case-for example, where an association seeks to enforce a zoning ordinance that applies both within and without the association's boundaries-the association's activity may produce spillover benefits for nonmembers. ${ }^{87}$

The enforcement role of the association also highlights a function that I have sketched above. I indicated in that discussion that covenants can embody proxies for activities and uses that association members wish to avoid. One way to think about such covenants is in terms of private lawmaking among individuals who wish to define nuisance more precisely or durably than definitions proffered by public bodies, for example, legislatures or courts. Covenants thus allow private zoning by those who, for instance, consider living next to a ostentatious house or a multistory dwelling to be an undesirable externality. Individuals who wish to opt out of public lawmaking because they find it too imprecise or-with respect to nuisances-underinclusive, may also desire to opt out of public enforcement mechanisms for fear that

8s See Erreca's v Superior Court, 19 Cal App 4th 1475, 24 Cal Rptr 2d 156 (1993) (suit against contractor); Sunshine Vistas Homeowners Ass'n v Caruana, 623 S2d 490 (Fla 1993) (enforcement of setback provision); Pleasant Ridge Townhouses Homeowners' Ass'n $v$ T \& D Construction Corp., 181 AD2d 871, 581 NYS2d 857 (1992) (action against town for defective construction); Oak Trail Road Homeowners Ass'n, Inc. v Royal Mile Corp., 246 NJ Super 590, 588 A2d 430 (1991) (action against warranty insurer). See also James L. Winokur, Reforming Servitude Regimes: Toward Associational Federalism and Communi$t y, 1990$ Wis L Rev 537, 537-40.

Professor Ellickson has indicated that the same result may be obtained by municipal enforcement of restrictive covenants. See Robert C. Ellickson, Alternatives to Zoning: Covenants, Nuisance Rules, and Fines as Land Use Controls, $40 \mathrm{U}$ Chi L Rev 681, 717 (1973). The problem with that solution is that municipalities may suffer substantial budget constraints on their ability to bring claims, and mundane complaints about violations of restrictive covenants could fall well behind other demands for municipal expenditures.

${ }_{86}$ See Cohen v Kite Hill Community Ass'n, 142 Cal App 3d 652, 191 Cal Rptr 209, 215-16 (1983). See also Duffey v Superior Court, 3 Cal App 4th 425, 4 Cal Rptr 2d 334, 338 (1992).

${ }_{87}$ See, for example, Wilson, 603 S2d 295; Shevock, 621 A2d 346; Strohm v Board of Zoning Adjustment of Kansas City, 869 SW2d 302 (Mo App 1994). 
those arbiters (courts) would bring to any dispute the perceptions created in litigation borne of the very public law principles that the residents are attempting to elude.

The association, as the initial interpreter of covenants, thus becomes the private arbiter of whether the events that give rise to the dispute before it in fact constitute a nuisance as that term is defined by those who have opted out of the more generally applicable legal standard. This does not necessarily require courts that review decisions by associations to defer to them (although I will shortly argue that they should). But it does suggest that one role of covenants, and of associations, is to permit those who find insufficient protection in the legal system to augment public law with private arrangements that are more responsive to their needs.

\section{The civic community model.}

To this point, I have suggested that associations may facilitate the formation of homogeneous communities by encouraging those with similar tastes to gravitate to a hospitable area in which they can pursue their vision of the good life. I have also suggested that associations may improve the allocation of goods within the broader society by allowing those who desire a particular package of local public goods to obtain them without either subsidizing or being subsidized by others with different tastes. Defenses of community, however, often rely on loftier virtues than mere preferences for homogeneity of tastes or lifestyles. For many, these preferences are related to participatory values that render associations susceptible to treatment as little democracies and potential fountainheads of civic virtue. ${ }^{88}$ By providing a forum for deliberation among interested parties and a means for resolution of public matters, residential associations, at least in theory, satisfy something akin to the Jeffersonian hope that participation by the electorate would be enhanced by turning the "counties into wards." 89

88 See, for example, Dilger, Neighborhood Politics at 131-33 (cited in note 1); Diana Jean Schemo, Escape from Suburbia: Community Associations Thrive Amid Debate on Freedom, Privacy and Democracy, NY Times B1 (May 3, 1994). For a statement of this objective, and some skepticism that it will be realized, see Gregory $\mathrm{S}$. Alexander, The Conditions of "Voice": Passivity, Disappointment, and Democracy in Homeowner Associations (Berkeley Institute of Governmental Studies, forthcoming 1994).

${ }^{89}$ See Letter from Thomas Jefferson to John Cartwright (June 5, 1824), in H.A. Washington, ed, 7 The Writings of Thomas Jefferson 355, 357 (J.C. Riker, 1855). 
Attractive as this model may be, its practical applications are dubious. If disputes involving homeowners associations centered on issues that indicated robust debate or civic virtue, we might infer that associations foster these values. For the most part, however, these disputes, at least as reflected in the reported cases, center on more mundane issues: satellite dishes, trailer homes, or architectural styles. ${ }^{90}$ Many, concerning efforts to collect assessments for financing collective goods after residents refused to make payments, reflect the failure of civic virtue. ${ }^{91}$ It is, of course, arguable that even these disputes may create a sense of community in that they involve residents in public processes, and that these initial measures may beget subsequent involvement in weightier issues. Nevertheless, I think that such byproducts are too far removed from the concept of civic virtue that liberal community purports to engender to admit these disputes as evidence of participatory movements within associations.

If we believed that litigation about such issues as fences followed from an internal debate about the kind of community that the residents were trying to create, then such litigation might well reflect the development of civic virtue. Yet no evidence of such interactions exists; in fact, there is some evidence that few residents participate in internal association politics. ${ }^{92}$ Attendance at association meetings is low (though not clearly lower than attendance at other collective decision-making bodies), and interactions among the association and neighbors may be adversarial rather than cooperative..$^{93}$ Thus, those who enter associations are less likely to be seeking to enhance their capacity for participatory self-governance, or their identity as active members, than to be seeking the solitude and protection that (given my claims about homogeneity) the associational lifestyle affords.

Nor should one expect otherwise given the governance structure of associations. Civic virtue is typically advanced by enfranchising those affected by the decision-making process. Association governance does not necessarily proceed in this fashion. Association voting schemes are typically based on property ownership rather than on the principle of one person, one vote. ${ }^{94}$ For in-

so See text accompanying notes $32-42$.

${ }^{91}$ See cases cited in note 71.

92 See Dilger, Neighborhood Politics at 139-40 (cited in note 1).

${ }^{93}$ See Winokur, 1989 Wis L Rev at 62-66 (cited in note 46).

94 See Dilger, Neighborhood Politics at 141-44 (cited in note 1); Ellickson, $130 \mathrm{U} \mathrm{Pa} \mathrm{L}$ Rev at 1543-63 (cited in note 30) (endorsing deviation from voting rules that apply to governments). For a rebuttal, see Frug, $130 \mathrm{U} \mathrm{Pa} \mathrm{L} \mathrm{Rev}$ at 1592-96 (cited in note 30). 
stance, renters are disenfranchised (although voting owners who wish to continue renting should be effective surrogates for their tenants' interests), and even those who have a vote may find themselves easily outvoted by those with more significant shares. ${ }^{95}$

Furthermore, to the extent that civic virtue, at least as embraced in some forms of communitarianism, affects shared understandings among different, but mutually respectful communities, ${ }^{96}$ it is noteworthy that much of the criticism of associations has been directed at their isolation from those outside the association. The exclusionary tendencies of associations does not necessarily mean that their values should be ignored or subordinated by courts. It does suggest, however, that it is difficult to defend associations as "minidemocracies" that are likely to inculcate political values that will spill over as robust citizenry in the larger society.

Even if we reject this application of the civic communitarian model, however, pieces of that model may explain much of the appeal of at least some associations. For instance, consider that legal doctrines that facilitate condominium conversions, urban gentrification, or economic development have been claimed to disturb longstanding neighborhoods in which established groups form homogeneous communities. ${ }^{97}$ These claims rest on an assumption that neighborhood stability is a positive good that fosters useful relationships among individuals. The Supreme Court has invoked similar claims about the desirability of neighborhood stability to uphold property tax schemes that discriminate in favor of longstanding residents. ${ }^{98}$ The stability of neighborhoods is vulnerable both to political processes, because zoning or changes in political boundaries may alter the scope of local activities, and to market processes, because demand for particular land

95 See, for example, Dilger, Neighborhood Politics at 142-43 (cited in note 1).

96 See Christopher J. Berry, Shared Understanding and the Democratic Way of Life, in John W. Chapman and Ian Shapiro, eds, 35 NOMOS: Democratic Community 67, 77-78 (NYU, 1993).

${ }_{97}$ See, for example, Poletown Neighborhood Council v Detroit, 304 NW2d 455 (Mich 1981); Note, Displacement in Gentrifying Neighborhoods: Regulating Condominium Conversion Through Municipal Land Use Controls, 63 BU L Rev 955 (1983).

${ }_{98}$ In Nordlinger $v$ Hahn, 112 S Ct 2326 (1992), the Court upheld a California property tax scheme that was based on the acquisition value of property rather than the fair market value of the property at the time the tax was levied. The Court concluded that the state's desire to preserve neighborhood stability and the reliance interest of purchasers against significant increases in taxes were sufficient to overcome Equal Protection Clause objections. Id at 2333 . 
uses may dictate the character of a neighborhood. Covenants, which have a permanence less susceptible to the vicissitudes of politics or markets, permit those who are particularly averse to neighborhood instability to contract with neighbors for an additional level of assurance. Thus, those drawn to associations may be those least confident that they will succeed in political disputes that affect the character of their neighborhood, a factor that, I will argue, may influence the extent to which we are willing to permit associations to impose on outsiders.

\section{Summary.}

To this point, I have tried to suggest the variety of explanations for associations and the covenants by which those institutions bind themselves. This discussion shows that associations do not perform a monolithic function, but offer different residents different advantages, ranging from service provision more consistent with resident preferences, to private lawmaking that embodies a lifestyle defined by residents, to community stability. Each of these objectives permits those who speak for the association to restrict the activities of members or the activities of outsiders that affect members. Thus, enforcement of association covenants creates the potential for conflict, and some of those conflicts are likely to require final resolution outside of the decision-making structures created by the association. When this happens, courts must address the issue of how much deference to grant to actions taken by the association. I next address the extent to which the functions and structure of association decision making affect this issue.

\section{IMPLICATIONS FOR JUDICIAL CONSTRUCTION OF COVENANTS}

A. Some False Starts-Voluntariness and the Analogy to Local Governments

The previous Section indicates that associations can satisfy certain socially useful objectives in a manner superior to that of traditional local governments. In achieving these goals, however, associations may be more successful at performing the allocative functions of government than the redistributive or educative ones. In addition, the exclusionary policies of associations will inevitably cause frictions both within the association and between the association and the larger society. We cannot readily conclude, therefore, that associations provide an untarnished opportunity to realize the blessings of decentralization. 
The extent to which associations provide benefits could, in theory, be advanced by allowing external review of their regulations. There is no a fortiori reason to suggest that associations should be able to escape a level of scrutiny that applies to local governments providing similar services. Nevertheless, associations are not governments, and the analysis above suggests that some of their benefits emerge from the very fact that they are not governments. Hence, it remains unclear whether associations should share the level of deference that is granted to local governments when associations purport to interpret and enforce the regulations that I have suggested define their character.

A common argument in favor of granting autonomy to associations is that relationships among members are voluntary, or at least more so than relationships among neighbors in municipalities. ${ }^{99}$ On this theory, the covenants of an association constitute a volitional contract, the terms of which are entitled to all the consideration that courts traditionally afford to contracting parties. Ambiguity in the meaning of covenants, on this view, should be resolved only by reference to the intent of the parties ${ }^{100}$ rather than to the reasonableness of their agreement. Decisions in which courts find explicit prohibitions on above-ground swimming pools ${ }^{101}$ or satellite dishes ${ }^{102}$ to be unreasonable independent of what the parties intended by inclusion of those prohibitions would, on this view, constitute unwarranted judicial interference with contract.

While the decision to live in an association can certainly be understood as a "voluntary" one, buyers' initial ignorance of the attendant covenants and their legal effects may give pause to any effort to rest too much on the parties' subjective volition. ${ }^{103}$ James Winokur contends that "[m]ost prospective owners do not

${ }_{99}$ See Cottrell $v$ Miskove, $605 \mathrm{~S} 2 \mathrm{~d}$ 572, 573 (Fla App 1992) (concluding that a restriction on the parking of commercial vehicles carried a strong presumption of validity because the resident voluntarily consented to the restriction when buying property); Jackson $v$ Williams, 714 P2d 1017, 1025 (Okla 1985) (Wilson concurring and dissenting); Ellickson, $130 \mathrm{U}$ Pa L Rev at 1519-20, 1523-24 (cited in note 30); Reichman, 43 U Chi L Rev at 279 (cited in note 49 ).

${ }_{100}$ See, for example, Krein $v$ Smith, 60 Wash App 809, 807 P2d 906, 907 (1991); Woodvale Condominium Trust v Scheff, 27 Mass App 530, 540 NE2d 206, 209 (1989).

${ }^{101}$ See, for example, Westfield Homes, Inc. $v$ Herrick, 229 Ill App 3d 445, 593 NE2d 97, 102 (1992).

${ }_{102}$ See, for example, Portola Hills Community Ass'n v James, 4 Cal App 4th 289, 5 Cal Rptr 2d 580, 583 (1992).

${ }^{103}$ For discussions of condominium owners' or homeowners' awareness of the covenants by which they are bound, see Natelson, 51 Ohio St L J at 61-65 (cited in note 31); Winokur, 1989 Wis L Rev at 56-62 (cited in note 46). 
intelligently review the restrictions to which they subject themselves upon acceptance of a deed to land burdened by servitudes."104 But ignorance does not translate into allowing purchasers to escape the effects of covenants. Especially in a legal regime that requires disclosure of covenants before the buyer enters a binding purchase contract, ${ }^{105}$ when the buyer could reasonably have investigated their terms, alone or with legal advice, it does not follow that we should reward those who fail to make more inquiries. In ordinary contract law, the absence of perfect information does not, of itself, render a decision "involuntary," if we mean by that conclusory term that courts need not enforce the agreement.

I do not assert the converse claim that all covenants are voluntary. Rather, my claim is that, even where homeowners lack knowledge or understanding of their covenants, little is to be gained by reducing the debate about association autonomy to one about "choice and choicelessness" for residents. ${ }^{106}$ Similarly, analysis of the scope of association autonomy is not much advanced by recognizing that even those who are aware of covenants may prefer only some of them, but are locked into a "coercive," all-or-nothing regime. ${ }^{107}$ As Glen Robinson has suggested, the dichotomy between fully free choice and coercion obscures the complicated question of when market failures become so severe that the buyers of bundled goods are acting under duress. ${ }^{108}$

Instead of seeking a single factor to separate coerced choices (subject to judicial rescission) from voluntary, binding choices, it may be more fruitful to consider whether purchasers can limit the enforcement of covenant restraints or obtain concessions in exchange for accepting them. Our reaction to constraints on choice may be very different if homeowners are exposed to arbitrary sanctions that they can neither control nor escape than if those same homeowners could reduce their exposure by exercising control over the conditions that might lead them to regret their decision.

108 Winokur, 1989 Wis L Rev at 59 (cited in note 46).

105 At least some states require sellers of homes in an association to make copies of covenants available to prospective purchasers. See note 52 .

${ }^{106}$ See Gregory S. Alexander, Freedom, Coercion, and the Law of Servitudes, 73 Cornell L Rev 883, 888 (1988).

107 See id; Winokur, 1989 Wis L Rev at 57 (cited in note 46).

108 Robinson, 91 Colum L Rev at 577-78 (cited in note 44). 
Consider residents of municipalities, who similarly must purchase bundled municipal services; they cannot, for example, decrease their property taxes by choosing private schools or contracting for private garbage collection. They presumably are able to use the political marketplace, augmented by judicial review of political decisions, to compensate for the "involuntary" choices to which they are subject. If associations that serve the same functions as municipalities provide similar opportunities for resident participation in decisions about what goods to provide and what characteristics to enforce, then one would imagine that we could afford private covenants the same deference that we grant to local officials without invoking the quandary of voluntariness. Thus, it may be worthwhile to explore the degree of latitude that courts grant to municipal decision makers.

Before turning to that question, however, one point about voluntariness is relevant to the discussion that follows. One might claim that if I am correct in my assumption that covenants serve as signals or proxies for the lifestyle of an association, then disclosure requirements that purport to increase information to potential residents should be superfluous since purchasers would already be fully informed about covenants. If I am correct, one might contend, covenants should be foremost in the minds of potential purchasers (which is unlikely the case) because covenants serve as the focal point of the purchase decision. Moreover, sellers should make the covenants conspicuous as selling points, and developers should market their properties on the basis of their covenants. Yet there is no evidence that any of these practices exists in the market for residents.

The signal of a covenant, however, can be sent implicitly rather than explicitly. The very homogeneity of the association may indicate the nature of the underlying covenants to observers, such as prospective purchasers. Thus, the absence of requests or advertisements based on those covenants does not necessarily imply their irrelevance to potential association members. Different covenants may be salient to different purchasers, and disclosure requirements ensure that prospective purchasers can learn of restrictions that would be important to them. But the fact that sellers initially tell a more sanitized story may simply reflect a desire to widen the market for their product. ${ }^{109}$

${ }^{109}$ My colleague Saul Levmore has suggested that law schools follow a similar pattern in creating catalogues that illustrate a rather picturesque learning environment, even though the underlying ethos of the law school is hard work. 


\section{B. Association Politics}

\section{The relational setting.}

I suggested above that judicial deference to associations might follow the scope of judicial review of municipal regulation. Unfortunately, any effort to discover that scope must confront the doctrinal fact that no single standard of judicial review governs all local regulations. In the absence of some constitutional or statutory provision to the contrary, the traditional rule of local government powers, Dillon's Rule, provides that local governments possess only those powers that have been explicitly delegated to them, or that are necessarily implied from express legislative grants. ${ }^{110}$ Doubts about the exercise of a power are to be resolved against the locality. ${ }^{111}$ Courts, therefore, play a substantial role in defining the scope of municipal autonomy and construing the meaning of state enabling statutes without necessarily acceding to the interpretations of municipal officials. Any analogy from ordinances to covenants based on Dillon's Rule similarly suggests that associations should have limited autonomy from judges.

The practical force of Dillon's Rule, however, has been reduced by state constitutional home rule provisions that explicitly abrogate narrow construction of local government powers and that permit local governments to initiate legislation without prior authority from the state. ${ }^{12}$ To make matters still more complex, some grants of home rule apply only to the most populous municipalities; few associations would satisfy the threshold figure. ${ }^{113}$ Thus, even if we wish to grant equal autonomy to associations and local governments, there seems as much reason to apply the background rule of strict construction to association

110 John F. Dillon, 1 Commentaries on the Law of Municipal Corporations $\$ 237$ at 448-49 (Little, Brown, 5th ed 1911). See, for example, Chemical Bank v Washington Public Power Supply System, 99 Wash 2d 772, 666 P2d 329, 334 (1983).

111 See, for example, City Council of Alexandria v Potomac Greens Associates Partnership, 429 SE2d 225, 228 (Va 1993).

${ }_{112}$ See, for example, Cal Const, Art XI, § 5; NM Const, Art X, §6; Williams v Town of Hilton Head Island, 429 SE2d 802, 805 (SC 1993); Des Moines v Master Builders of Iowa, 498 NW2d 702, 703-04 (Iowa 1993).

${ }_{113}$ See, for example, Colo Const, Art XX, $\S 6$ (home rule for cities and towns with population in excess of 2,000 ). In any case, home rule provisions "can be nullified through actual usage." See Comment, Give 'Em Enough Rope: States, Subdivisions and the Market Participant Exception to the Dormant Commerce Clause, 60 U Chi L Rev 615, 637 \& n 128 (1993). 
covenants as there is to assume that associations possess significant latitude. ${ }^{114}$

The better way to resolve the issue of the judicial role is to ask why we might want substantial review of local decisions, and whether those same concerns affect decision making by associations. I have previously argued that Dillon's Rule is best understood as a mechanism for controlling interest group domination of parochial activity. ${ }^{115}$ The Rule allows courts to monitor decisions that appear to have been made at the behest of an influential local minority, or without representation of a disadvantaged minority. Hence, the Rule addresses the Madisonian concern for dominant factions, which are more likely to triumph at a decentralized level since centralized decision making provides greater opportunities for competing factions to organize and engage in a deliberative debate. ${ }^{116}$ The negative implication of this proposition is that where all those affected by local decision making are represented, discrete interest groups presumably will be unable to exploit the unrepresented or to capture the decision-making process. Under these conditions, the need for judicial intervention to safeguard the unrepresented (or underrepresented) is reduced.

Political processes in municipal decision making, therefore, are not important solely for their own sake (although I do not want to trivialize the value of participatory processes ${ }^{117}$ ), but rather because they help to accommodate the diverse and competing interests that exist in a municipality. Under these conditions, politics are necessary to decide the service package that will be available for any locality. Those with different tastes will be expected to become involved in the political process, to make their preferences known, and to compromise in order to ensure that residents with different preferences obtain a fair share of the municipal budget and that none are systematically disadvan-

114 Some states require that the regulatory actions of associations be "reasonable," see text accompanying note 56 , a term that requires judicial construction in each particular setting. One might infer that such requirements authorize substantial judicial intervention in regulation by associations. Nevertheless, courts may undertake review for reasonableness with a presumption of validity or not, and the choice that the court makes along these lines will substantially affect the outcome of the cases it reviews.

115 Clayton P. Gillette, In Partial Praise of Dillon's Rule, or, Can Public Choice Theory Justify Local Government Law?, 67 Chi Kent L Rev 959, 983-85 (1991).

${ }^{116}$ Federalist 10 (Madison), in Clinton Rossiter, ed, The Federalist Papers 77, 83 (Mentor, 1961).

117 For an examination of arguments for and against participatory processes in government, see Clayton P. Gillette, Plebiscites, Participation, and Collective Action in Local Government Law, 86 Mich L Rev 930 (1988). 
taged by municipal regulation. At the same time, because representatives of some interests will better be able to organize or to influence decision makers in ways that do not reflect the merits of their case, we do not want to depend entirely on political processes to allocate scarce resources among competitors. Hence, some external intervention, typically in the form of judicial interpretation of municipal authority, will be necessary to approximate optimal local expenditures.

Judicial intervention, however, is not always beneficial. Courts are not necessarily adept at distinguishing process failures from situations in which the minority was simply outvoted by a sympathetic but unpersuaded majority. Thus, courts may decide cases based more on a personal view of the proper substantive result than on the actual failure of a process. ${ }^{118}$ Similarly, courts cannot readily assess the regulatory needs of localities when deciding whether particular regulations were authorized, so that failure to consider the peculiar features of localities will lead to invalidation of desirable local activity. Thus, more judicial intervention is not necessarily better, even where the potential advantages of a privileged interest group threaten to skew local decision making.

But if judicial intervention is necessary primarily to referee the process by which diverse groups compete for the resources and regulatory apparatus of the locality, then the need for it dissipates as the locality becomes more homogeneous and the threat of one group dominating others diminishes. With this possibility in mind, consider again the characteristics of associations. As with residents of localities generally, residents of associations will not have achieved the conditions required by the perfect Tiebout model. ${ }^{119}$ They will not have perfect mobility, or

${ }^{218}$ See Einer R. Elhauge, Does Interest Group Theory Justify More Intrusive Judicial Review?, 101 Yale L J 31, 60-61 (1991).

Judicial review of municipal expenditures is especially problematic. Budget decisions are polycentric, so that funding levels for one activity may depend on funding levels for other activities. The amounts allocated to police services may vary with the amounts allocated to schools, since, for instance, more after-school activities funded through the school budget can reduce the need for police services during that time. While political legislatures can attend to all parts of the budget and trade off expenditures in a manner that reflects all interests, courts can only consider the distinct claims before them and hence may fail to consider the basis or consequence of budget allocations on projects that are not represented in the immediate litigation. See, for example, Riss $v$ City of New York, 22 NY2d 579, 240 NE2d 860 (1968); Chandler $v$ District of Columbia, 404 A2d 964, 966 (DC App 1979).

119 See Tiebout, $64 \mathrm{~J}$ Pol Econ at 419 (cited in note 8). Under the Tiebout model, each individual is able to migrate to a jurisdiction that offers local public goods that perfectly 
perfect information, or an unlimited number of associations from which to choose when they make decisions about residence. Hence, when conflict arises among association members as a result of ambiguities in covenants, changes in peoples' preferences about the desirability of particular covenants, or the occasional refusal of individual members to abide by the norms implicit in those covenants, we cannot rely on the Tiebout solution of mobility to reduce friction. Judicial intervention may be feasible in such cases, just as in disputes about municipal regulatory authority.

As in those cases, however, judicial intervention is not an unqualified benefit. Courts that err when construing ambiguities, or that restrict associations from enforcing covenants, impose on associations the very activities that a majority of the association had agreed to avoid. Indeed, the desire to avoid the externalities from such activity may have been the primary motivating factor for joining the association to begin with. Judicial misconstruction thus distorts the signals sent by covenants about the nature of the association. Judicial scrutiny of the meaning or reasonableness of covenants, therefore, is desirable only if the risk of judicial error is outweighed by the possibility that the association will enforce covenants in a manner inconsistent with the common vision of association members.

The costs of judicial intervention may be worth incurring, for instance, if we believe that residents would otherwise be vulnerable to strategic behavior by the association or by a nonrepresentative subgroup of residents that had captured association decision making. These defects in the political process, I have suggested above, are just the factors that validate judicial scrutiny of municipal decision making. On the other hand, we would take more comfort in relying on associations to construe and administer covenants free from judicial intervention if we were confident that association decisions systematically represented the consensus of members' views rather than a failed political process within the association.

I think that there are reasons to believe that these latter conditions will hold, so that association autonomy should be favored over strict construction and scrutiny of covenants. The basis for my conclusion lies in the very homogeneity of associations that frequently serves as a basis for their being criticized.

correspond to his or her preferences. Hence, political battles are unnecessary to resolve competing claims to goods and services. 
Homogeneity implies that, within the association, the sources of friction within municipalities-selection of goods or services that are to be provided, the definition of permissible activities, and the avoidance of externalities-have already been resolved. The existence of homogeneity suggests that minority interests are less likely to arise, since residents presumably share a common vision embodied in the covenants. While factions do arise in small groups, such as families or religious sects, the voluntary nature of associations suggests that individuals have selected for the characteristics of the neighborhood, and the substantial investment that they make in home purchases implies comfort with the character of the area. ${ }^{120}$ This common vision does not mean a frictionless subsociety, and the difficulty of exit suggests that association members are likely to be vulnerable to strategic behavior in the interpretation of covenants. Nevertheless, the homogeneity of associations suggests that internal friction is less likely to be caused by unsympathetic interests dominating the decision-making process. Hence, the need for external constraints in the form of judicial intervention is reduced.

The conditions necessary to this conclusion should be familiar to students of relational contract. Principles of relational contract suggest that self-policing may be superior to judicial policing against chiseling on the relationship in settings characterized by continuous interactions among parties who are bound to each other either voluntarily (for example, through contract) or by circumstance (for example, by virtue of being neighbors), who cannot exit the relationship easily (primarily because of investment in transaction-specific assets ${ }^{121}$ ), and who depend on reputation for benefits from others (a function of being members of the same decentralized community). ${ }^{122}$ This proposition holds in contractual settings, because the terms of the agreement that generate disputes are likely to revolve around vague principles not readily susceptible to judicial measurement. Hence, even though we might be able to articulate a general

120 Religion and family are less volitional in that exit from one's original religion or family is difficult, if not impossible. Furthermore, factions within some groups, such as religions, are likely to arise as a result of the need of a subset of the group to adapt to new circumstances. The geographical compactness of associations suggests that such adaptations are likely to be unnecessary.

${ }^{121}$ See Oliver E. Williamson, Transaction-Cost Economics: The Governance of Contractual Relations, 22 J L \& Econ 233, 239 (1979).

${ }^{122}$ Charles J. Goetz and Robert E. Scott, Principles of Relational Contracts, 67 Va L Rev 1089, 1149-50 (1981). 
standard, such as "best efforts," to which relational parties should aspire, ${ }^{123}$ judicial attempts to determine when that standard has been satisfied are vulnerable to significant error. Those who participate in the practice defined by such standards, however, are likely to be capable both of defining them and of detecting defections from the cooperative norm.

Relationalism explains how neighbors may evolve a set of mutually beneficial norms that govern their unique circumstances, even when those norms contravene positive law that applies to the broader society. ${ }^{124}$ Norms have the feature of being sustained by the approval or disapproval of those who share them. ${ }^{125}$ Becoming a party to a relationship governed by norms indicates that membership is important to the actor and that the actor wants to associate with others who define themselves as governed by similar norms. Therefore, where there exists a shared understanding of the ways in which parties in the relationship are to conduct themselves, failure to comply can damage one's reputation within the group. The high exit costs associated with relational settings indicate that those who violate the norms will have difficulty avoiding punishment, since the only escape lies in departure from the relationship. Since each party to the relationship stands in a position both to impose reputational harms on others and to suffer reputational harms at the hands of others, reciprocal compliance with the norms is likely to evolve and endure. ${ }^{126}$ Thus, norms that evolve within a relational setting may become self-enforcing within the group. From these characteristics of relationalism there flows a legal conclusion: The combination of vague terms that can only roughly specify the nature of the relationship combined with extralegal enforcement mechanisms by those who can fill in the details of the relationship may create a situation in which legal (judicial) enforcement

${ }^{123}$ Id at 1111-19.

124 The classic article for this proposition is Stewart Macaulay, Non-Contractual Relations in Business: A Preliminary Study, 28 Am Soc Rev 55 (1963). A more recent and wide-ranging application is found in Robert C. Ellickson, Order without Law: How Neighbors Settle Disputes 141-44 (Harvard, 1991).

125 See Jon Elster, The Cement of Society 99-100, 105 (Cambridge, 1989). See also Robert E. Scott, Conflict and Cooperation in Long-Term Contracts, 75 Cal L Rev 2005, 2040-42 (1987). Note that I am simply attempting to describe the effects and consequences of norms. I am not making any claim that the norms that evolve will maximize the welfare of those who share them. For a stronger claim, see Ellickson, Order without Law at $167-83$.

${ }^{126}$ See Ullmann-Margalit, Emergence of Norms at 21-22 (cited in note 77). 
is inferior to reliance on the parties themselves to keep the common understanding together.

The purchase of a residence within an association bears the characteristics of a classic relational contract. The transaction constitutes an investment in specialized resources, as the residence will likely be inappropriate for other uses, and even transformation of the property into a rental property may be difficult. Exit from the transaction (selling and moving to a different home) is difficult given the costs (fiscal and emotional) of uprooting. This difficulty of exit suggests that the purchaser expects to remain in the property for a substantial period of time. Since other purchasers within the association face similar constraints, each resident expects repetitive interactions with neighbors. "Misbehavior" by violation of the association's norms, therefore, is open to substantial opportunities for punishment through informal mechanisms of gossip, shunning, or infliction of other reputational injury. ${ }^{127}$

Thus, the transaction by which a homeowner becomes subject to covenants is a contractual one, regardless of whether one wishes to append the additional description of "voluntary." But it is a contract of a particular type, and a type that has been misunderstood by those who criticize the contractual approach to the question of covenants. For instance, Gregory Alexander contends that economic perspectives on associations are insufficient because they rely on formal contractual structures rather than social relations. Alexander writes that a contractarian model of relations among homeowners:

leads it to ignore the character of social relations within residential groups. As a result, it fails to distinguish between residential groups that are held together only by mutual collaboration and convenience, and those in which individuals choose to live together because of more deeply shared values. ${ }^{128}$

Alexander's vision presents an overly constrained image of what is entailed in the contract among homeowners. Far from the discrete, rule-bound transaction that Alexander assumes is implicit in economic explanations of contract, ${ }^{129}$ the quintessentially relational structure of the transaction necessarily means

127 See Ellickson, Order without Law at 56-60 (cited in note 124).

${ }_{128}$ Alexander, 75 Cornell L Rev at 40 (citation omitted) (cited in note 13).

129 Id. 
that attention must be paid to the "social relations" within the group in order to determine, from an "economic" or "contractarian" perspective, the proper interaction between association practices and legal intervention. These social relations compensate for covenants' inability to detail the relationship completely at the outset, and constrain the subsequent efforts of any party to maximize self-interest in the interpretation of the contract.

Indeed, Alexander implies that the very processes that create incentives for cooperation among association members are invidious. The fact that exit costs are nontrivial for each party transforms the relationship into something like a multilateral monopoly (or bilateral monopoly, if we describe the relevant parties as the landowner who seeks to engage in a prohibited land use and, as a group, all other homeowners within the association). Alexander, writing in the somewhat different context of the capacity of covenantors to escape their promises after conditions have changed, concludes that bilateral monopoly prevents each party from experiencing "the liberation of an unconstrained market; both sides feel themselves in servitude to each other."130 Intervention from some "external source," presumably the law or-more specifically - the judiciary, is necessary to "enable the parties to do what they lack the power to do themselves." Since Alexander's concern is with the inability of the parties to exit, rather than with the context of obsolete covenants, his criticism seems to be directed at the bilateral monopoly inherent in the construction of association covenants as well.

Stewart Sterk, while less optimistic about the law's capacity to resolve issues for the parties, also raises the likelihood that bilateral monopoly induces the type of strategic behavior that will impede bargaining. ${ }^{132}$ Professor Sterk, however, recognizes the point implicit in the existence of relationalism: relations that form as a result of a bilateral monopoly from which neither party can easily exit may generate norms that actually reduce strategic behavior. ${ }^{133}$ Where repeat play is inevitable because exit costs are high, as in relations between neighbors, bilateral monopolies may force individuals into cooperation because these same condi-

${ }^{130}$ See Alexander, 73 Cornell L Rev at 899 (cited in note 106).

131 Id at 899-900.

132 See Stewart E. Sterk, Neighbors in American Land Law, 87 Colum L Rev 55, 69-88 (1987).

${ }^{133}$ Id at $89 \&$ n 120. 
tions enhance opportunities for revenge or retaliation. For each homeowner, the investment in residence entails a relationship in which each is solicitous of the other's needs and interprets contractual ambiguities in light of their mutual interests. ${ }^{134}$ Hence, if one focuses on the nature of the relationship, the "contract" between the parties takes on a much richer texture than Alexander's image permits.

Nevertheless, as I have suggested above, the informal processes of relational norms will not make cooperation perfect. ${ }^{135}$ Should association members fail to obtain satisfaction for an alleged violation of a norm embodied in a covenant, they possess an additional form of redress: enforcement of the covenant by the association. It is at this point that the question of association autonomy arises. The capacity of the association to satisfy the functions for which it is created ${ }^{136}$ depends substantially on the latitude granted by courts reviewing its construction of covenants.

\section{Courts and associations as interpreters of covenants.}

An association's covenants may be thought to vary in one important respect from the relational theory that I have described above. One indicium of a relational contract is the unwillingness or inability of the parties to reduce the nature of their relationship to precise terms. The fact that the relationship will unfold over a substantial period of uncertainty means that parties will not want to allocate contractual risks based on current circumstances. Instead, relational parties may wish to deal with uncertainty by defining standards for performance in "unusually general terms." 137 These terms signal to both the parties and a court attempting to resolve any dispute between them that the contract involved an effort to share unanticipated and unallocated risks that materialize as the relationship evolves. Given the risks that might emerge with the passage of time, general terms indicate only an intention to cooperate. Where no alternative explicit bargain appears on the face of the contract, it is rational to assume that the parties intended to maximize their

134 See Gidon Gottlieb, Relationalism: Legal Theory for a Relational Society, 50 U Chi L Rev 567, 569-73 (1983).

${ }^{235}$ See Ellickson, Order without Law at 29-39 (cited in note 124); Scott, 75 Cal L Rev at 2041 (cited in note 125).

${ }^{136}$ See text accompanying notes 76-87.

137 Goetz and Scott, 67 Va L Rev at 1092 (cited in note 122). 
joint interest rather than to allocate losses resulting from unanticipated risks in some other manner. ${ }^{138}$ Similarly, where an ambiguity appears as a result of vague terms, it makes sense to resolve the ambiguity against the background signal of joint maximization embodied in the contract. ${ }^{139}$

Unlike traditional relational contracts, however, covenants tend to be quite specific. Relationalism is inherent in a contractual clause that requires "best efforts." But "no dogs" means "no dogs" simpliciter; relationalism, one might claim, is irrelevant to a proper construction of the term. It would be possible to draft covenants that speak in broad, general terms, or that specifically reference an intent that community practices be interpreted in a manner consistent with the mutual interests of the residents as expressed by the homeowners association. This would be the functional equivalent of a "renegotiation clause" that might signal a risk-sharing obligation in a commercial context. Indeed, some covenants contain what may be considered the equivalent of such a clause, which might inform the proper interpretation of more specific covenants. ${ }^{140}$ Thus, one might conclude that fail-

${ }^{138}$ See Robert E. Scott, A Relational Theory of Default Rules for Commercial Contracts, $19 \mathrm{~J}$ Legal Stud 597, 602-04 (1990). I have previously argued that, with respect to some historically remote risks, parties might be assumed implicitly to have engaged in an alternative allocation of risks. See Clayton P. Gillette, Commercial Relationships and the Selection of Default Rules for Remote Risks, 19 J Legal Stud 535 (1990).

${ }^{239}$ In some respects, however, the vagueness of the relationship suggests that courts stand in an inferior position to comprehend and enforce the details of the relationship. The fact that the court can recognize that joint maximization was the objective of the parties does not mean that the court can also identify what conduct would constitute joint maximization. Any effort to define the point of joint maximization is prone to error and would undermine the parties' incentives to specify their contractual obligations as fully as possible. Instead, the better position for courts may be to allow the inducements that emerge from the parties' reciprocal capacities to punish any party perceived to be chiseling at the original understanding.

${ }_{140}$ A covenant in the Declaration of Covenants, Conditions and Restrictions for Ashcroft, a development in Albemarle County, Virginia reads:

The Developer has deemed it desirable, for the efficient preservation of the values and amenities in the community, to create an agency to which should be delegated and assigned the powers of owning, maintaining and administering the common properties and facilities, administering and enforcing the covenants and restrictions, collecting and disbursing the assessments, dues and charges hereinafter created, and promoting the recreation, health, safety, common good and general welfare of the residents. In this regard, the Developer has incorporated under the laws of the State of Virginia the Ashcroft Neighborhood Association as a non-profit corporation for the purpose of exercising such functions.

(on file with $U$ Chi L Rev). For an example of a court that referred to such a general recital in the Declaration of Covenants, Conditions and Restrictions to define the meaning of a restriction on "trailers," and that upheld the association's application of the restriction, 
ure to include such a provision constitutes an implicit indication that covenants do not evince any cooperative intent. The judiciary, on this reading, suffers no disadvantage in determining whether the conditions of compliance with precise covenants have been satisfied.

Specificity of covenants, however, does not necessarily mean that the parties do not recognize their relational situation or do not rely on norms of reciprocity to enforce it. Other explanations may suffice. First, it may be that property regimes historically require greater specificity than commercial regimes. The relaxation of requirements of definiteness in commercial contracts, such as the ability to have an enforceable contract with an open price term, ${ }^{141}$ does not appear to have spilled over into the traditional insistence in real property contracts on specificity and detail. Thus, specific clauses standing alone do not betoken a lack of cooperative intent.

Second, specific covenants may establish the parameters of the relationship without exhausting the details. Just as covenants provide strong signals about the lifestyle of association members, so do they provide a basis from which to extrapolate when the association attempts to advance that lifestyle in ways that are not explicit in the covenants themselves. The specificity of the covenants, however, provides limitations that frame the relationship. Thus, specific restrictions on activities and uses play much the same role that has been attributed to binary, winnertake-all legal rules in long-term relational contracts. Given the incentives for cooperation in such transactions, one might imagine that binary rules that apply to discrete contracts would be superfluous or would give way to an exhaustive litany of rules drafted by the parties to resolve all contingencies. As Robert Scott indicates, however, binary rules play an important role even in situations dominated by relational norms:

The cooperative model resolves the apparent paradox of legal enforcement. Under this conception, the many binary contract rules serve as effective complements to the more flexible extralegal mechanisms that regulate adjustment. More complex, multifactored rules may thus be undesirable to most contracting parties because they sacrifice clarity in 

return for only marginally reinforcing existing patterns of
cooperation.

Similarly, developers and associations are unlikely to find it worthwhile to invest in drafting a complete contingent list of covenants that define the lifestyle preferred by residents. Instead, representative clauses may serve as signalling devices by indicating those activities and uses of greatest concern, while implying that potential residents to whom those clauses would be salient will share other preferences of lesser concern. The presence of specific clauses, therefore, neither abrogates cooperative intent nor denies the need to work out future disputes through relational norms.

Once we recognize the force of relationalism, judicial intervention may still be useful to enforce the implicit norms of cooperation when inevitable disputes arise. ${ }^{143}$ Legal review of the enforcement of covenants may avoid spiteful actions against an outlier within the community ${ }^{144}$ or may clarify ambiguities where the meaning of a covenant is substantially in doubt even among members. ${ }^{145}$ External checks on the interpretation of relational contracts, however, make the most sense where the adjudicating body has substantial expertise in the area at issue, or is otherwise sufficiently familiar with the use of language by the disputants. ${ }^{146}$ Llewellyn's endorsement of merchant juries in commercial cases, for instance, was largely motivated by his sense that merchants alone would be sufficiently familiar with the specialized use of language and practice in commercial contracts to render verdicts that accurately reflected the intentions of the parties. ${ }^{147}$

As a general matter, the setting in which disputes over covenants arise does not inspire confidence that courts have an ad-

142 Scott, 75 Cal L Rev at 2050 (cited in note 125).

143 See id at 2042-44.

14 See, for example, Portola Hills Community Ass'n v James, 4 Cal App 4th 289, 5 Cal Rptr 2d 580 (1992) (imposing sanctions against a community association for pursuing an action against a lot owner who installed a satellite dish without receiving the permission of the association).

145 See Scott, 75 Cal L Rev at 2042 (cited in note 125).

146 Id at 2043-44.

${ }^{147}$ See Zipporah Batshaw Wiseman, The Limits of Vision: Karl Llewellyn and the Merchant Rules, 100 Harv L Rev 465, 512-13 (1987). See also Scott, 75 Cal L Rev at 203738 (cited in note 125) (Parties in relational contracts governed by cooperative norms "may have difficulty escaping the standardized arrangements [of legal rules] since any interpretive disagreements are likely to be resolved by judicial recourse to the very same context that contractual innovators seek to escape."). 
vantage over the informal interpretive processes of associations. The relational nature of the community provides a reason for believing that when cooperation breaks down sufficiently to require a lawsuit, the association's interpretation of the covenant is likely to represent the common understanding of its members. Courts, on the other hand, are likely to miss any gap between the association's understanding and the understanding outside the association. While ambiguous signals may be misunderstood by some members, where a critical mass (critical enough to persuade the association to undertake a lawsuit) of those who respond to these signals and who live within the community governed by them have a common view of their meaning, that interpretation is more likely to be accurate than the interpretation of a court sitting outside the community. Development of and within the community may give a covenant subtly, but importantly, different meanings than those outside the relationship would attribute to it. Indeed, although he was writing of groups more defined by ethnicity than geography, Robert Cover's description of the evolution of normative narratives within a private community seems to have substantial fit with the lawmaking efforts by those within an association. ${ }^{148}$ Thus, the occasional court that recognizes how homeowners develop a context in which covenants are to be understood, and that the wording of those covenants may take on meaning different from the same words as understood outside the community, are acting most consistently with the purposes that underlie the development of associations. ${ }^{149}$

From this perspective, it is important that it is the association that is enforcing the covenants. Consider, for instance, the situation in which one resident of the association brings an ac-

148 The point that is relevant here is not only that private lawmaking takes place through religious authority, contract, property, and corporate law (and of course through all private associational activity), but also that from time to time various groups use these universally accepted and well-understood devices to create an entire nomos-an integrated world of obligation and reality from which the rest of the world is perceived. At that point of radical transformation of perspective, the boundary rule-whether it be contract, free exercise of religion, property, or corporation law-becomes more than a rule: it becomes constitutive of a world. We witness normative mitosis. A world is turned inside out; a wall begins to form, and its shape differs depending upon which side of the wall our narratives place us on.

Robert M. Cover, Foreword: Nomos and Narrative, 97 Harv L Rev 4, 31 (1983).

${ }_{149}$ See, for example, Lakes at Mercer Island Homeowners Ass'n v Witrak, 61 Wash App 177,810 P2d 27 (1991) (concluding that tall trees may constitute a "fence" in violation of a covenant because that interpretation "protects the homeowners' collective interests" and satisfies the "objective of the contract," even if it is inconsistent with the "plain meaning" of the term). 
tion against another for violation of a covenant. ${ }^{150}$ After entering into the association, it may be in the interest of each member to retain maximum individual autonomy for himself or herself while restricting the autonomy of others. In this manner, residents who seek the refuge of covenants to prevent others from imposing externalities on them may still attempt to impose externalities on those others; the fact that I do not want to look at your ranch-style home in our federalist-style neighborhood does not mean that I do not want to require you to look at the commercial vehicle that I park in my driveway.

As noted above, the enforcement of covenants constitutes a contractual solution to this dilemma. Given the free-rider nature of redressing violations of community norms, however, one would expect that enforcement actions would be brought by cocovenantors only when they have idiosyncratically high interests in the violation. Typically this will occur between immediate neighbors or others in close geographical proximity to the subject of the complaint. ${ }^{151}$ The fact that one party resorted to litigation, moreover, indicates that the relational and reputational constraints that normally prevent the public eruption of neighborly disputes have failed. The very breakdown of these norms, however, makes it difficult to tell, ex ante, whether the failure occurred because the homeowner against whom the complaint has been filed is chiseling on the common understanding or because the complaining neighbor is trying to maximize restrictions on others. The particular violation may impose on the neighbor costs sufficiently great to outweigh the benefits of neighborly relations. Alternatively, the neighbor may have idiosyncratically little taste for neighborly relations. Indeed, if neighborly relations have already disintegrated, institution of a lawsuit may be a matter of spite. In short, where litigation about a covenant materializes between two neighbors, ${ }^{152}$ it is unclear whether the alleged violator or the complainant has misunderstood the community's sense of the covenant or whether one of the parties is attempting to capture some idiosyncratic gain. In neighbor/neighbor disputes, therefore, the arguments about relationalism do not compel judi-

${ }^{150}$ See, for example, Sargent $v$ Smith, 863 SW2d 242 (Tex App 1993); Ingram $v$ Wirt, 314 Ark 553, 864 SW2d 237 (1993); Crabtree $v$ Jones, 435 SE2d 823 (NC App 1983).

${ }^{151}$ See, for example, Ingram, 864 SW2d at 238 (next-door neighbor); Crabtree, 435 SE2d at 823 (across the street).

${ }_{152}$ See, for example, Chicago Title and Trust Co. $v$ Weiss, 238 Ill App 3d 921, 605 NE2d 1092 (1992) (granting standing to an individual resident of a planned unit development to enforce restrictive covenants against a neighbor). 
cial deference to one party's interpretation of the covenant rather than the other's. Hence, judicial intervention to interpret the covenant may be appropriate or necessary, notwithstanding the relationship.

Consider the analogous situation in which courts intervene to determine whether a party to a contract has complied with the kind of "best efforts" clause that characterizes some relational contracts. ${ }^{153}$ Even if there is agreement that the clause requires each party to the dispute to maximize the joint product rather than personal profit, ${ }^{154}$ each party has reason to favor a particular interpretation of what action would satisfy that vague criterion. Given the interests of the claimants, there is no inherent reason for the court to entertain a presumption that either party's interpretation more accurately reflects the initial understanding of the parties.

An action by the association, however, is more likely to involve a complaint against an actual defector from the relationship. A board of directors is unlikely to bring a costly and timeconsuming action in the association's name until it has heard multiple complaints against a neighbor, made an independent investigation, and attempted informal resolution of the matter. Where the association decides to proceed, therefore, it is unlikely that the complainers have been idiosyncratic. Since the association acts on behalf of all members (while the individual complainant speaks only for himself or herself), its interpretation is more likely to reflect the common understanding of members than an interpretation of any one party. Given the relationship among members, it is unclear why a court, left to its own devices, should attempt to do anything more than comprehend that same understanding.

This analysis implies that presentation of the same issue-interpretation of a covenant-in two different judicial proceedings, one initiated by the association and one initiated by an individual member of the association, may properly carry different presumptions. The action by the association can be presumed to reflect the current understanding of its members as to the meaning of the contested covenant. The same action, initiated by an individual member, carries no such cachet. Courts that treat interpretation of all covenants the same, regardless of the identities of the disputing parties, fail to make this distinction. 
Indeed, there is a colorable argument for an additional presumption based on the identities of the parties, although I find it unpersuasive. Given the costs (both financial and reputational) inherent in bringing lawsuits, one would imagine that even the idiosyncratic neighbor would prefer to have the association bring the lawsuit alleging a covenant violation. One might therefore infer that the individual action was brought only because the association refused an initial request. Arguably, this refusal indicates that the association believed that there was no violation of the current understanding of the covenant; hence, the existence of the individual lawsuit might justify a presumption against the plaintiff's interpretation in the individual case.

I am unwilling to endorse this conclusion only because there might exist alternative explanations for association inaction, even where the plaintiff's interpretation of the covenant is correct. The association, which must act in the interests of all the members, not just the complainant, may believe that the harm caused by the violation does not justify the expense of a lawsuit. ${ }^{155}$ Alternatively, the association may be willing to bring a lawsuit, but only after a period of negotiation with the violator that the individual neighbor is unwilling to tolerate. Hence, I reject the strong conclusion in favor of a weaker one that provides only that an individual plaintiff is not entitled to the same presumption of a violation that should exist when the association brings the action.

Finally, note that, when based on the cooperative relationship among association members, judicial deference to the association's construction of its covenants is actually more consistent with the policies that disfavor restrictions on land uses than is the traditional doctrine of strict judicial construction of covenants. ${ }^{156}$ The doctrine of strict construction emerges from antipathy to restraints on the alienation of land and a fear that future productive uses of property will be prohibited by outdated limitations. Reliance on relationalism, however, serves the very goal of retaining flexibility of land use by permitting the association to interpret covenants dynamically to reflect the changing preferences of the community. Courts that stand outside the community will have a more difficult time discerning shifts in those

155 See, for example, Beehan v Lido Isle Community Ass'n, 70 Cal App 3d 858, 866, $137 \mathrm{Cal}$ Rptr 528, 532 (1977) (holding that an association's failure to take action against construction arguably in violation of a setback restriction was protected by the business judgment rule).

${ }_{156}$ See text accompanying notes $46-47$. 
preferences, and failure to accede to the interpretation of the association may bind courts to a more rigid interpretation of covenants than the association itself would endorse. Assume, for instance, that a covenant bars "fences" higher than six feet during a period when wooden fencing is a primary mechanism for marking boundaries on lots within the association. A homeowner now plants a row of saplings on her boundary and allows them to grow in excess of six feet. A court applying the traditional rule would have difficulty enjoining the maintenance of the "fence," notwithstanding that the function of the covenant was to ensure unimpeded views for all residents at a time when traditional fencing posed the primary threat. ${ }^{157}$

There is, however, a dark side to this justification. Dynamic interpretation may permit the association to enforce covenants in a manner consistent with the understanding of a majority of homeowners at a given time. That same dynamism, however, may mean that residents who joined the association under one set of signals will be frustrated by subsequent developments. Extreme changes that would substantially frustrate expectations might be rare for the same reasons of relationalism that make interpretation by the association useful. Nevertheless, there may be occasions in which developing interpretations do substantially shift away from the original understanding of some homeowners. These shifts impose real costs on homeowners, who at some point may decide that the community is no longer compatible with their preferences. That result does not mean that the community has acted improperly. Instead it suggests that, notwithstanding the increased stability that one receives through covenants, communities-like municipalities or other voluntary organizations-may alter identities over time and the result may adversely affect those who relied on earlier personalities. As when localities decide to provide new services or to cease providing existing services, however, that result does not necessarily translate into opportunities for legal redress.

One additional constraint on association autonomy should be apparent from the relational justification for judicial deference. Some intra-association disputes do not arise in situations that promise the repeat play that underlies my claim for association autonomy. Assume, for instance, that a covenant prohibits the installation of "trailers" within the association, and that a resident places on her property a structure that is prefabricated and 
that is blocked on a lot without a permanent foundation. ${ }^{158}$ Should a conflict arise about whether the structure constitutes a "trailer," victory for the complainant essentially requires removal of the structure and, most likely, of the violator as well. In this situation, the parties face an endgame strategy in which cooperation is not compelled. Thus, there is little reason to believe that the reputational constraints that apply when neighbors anticipate a prolonged relationship will ensure that the association is interpreting the covenants in a manner consistent with the common understanding. Nevertheless, the fact that the association can only assume an endgame when it is relatively certain of victory will itself be a constraint on its ability to offer idiosyncratic constructions of the covenant.

\section{Agency Costs in Residential Associations}

To this point, my argument has been that judicial deference to association interpretation of covenants is appropriate because the very commencement or defense of a lawsuit signals courts that a violation of the community norm has occurred. This conclusion, however, is predicated on an assumption that those who make decisions that bind associations, typically the board of directors, are representative of the association's members. To the extent that this is not true, the relationship between the parties provides little reason for the court to favor one interpretation of the covenant over another. Hence, competing policies, such as the traditional policy of construing servitudes narrowly, may trump any appeal to association autonomy. It is necessary, therefore, to examine whether there are reasons to believe that governors of an association will tend to reflect or not to reflect the common understanding of its members.

As in the context of business corporations ${ }^{159}$ and local governments, the greater the divergence between the interests of decision makers and their constituents, the stronger the argument for judicial intervention in reviewing decisions. ${ }^{160}$ There

${ }_{159}$ See Angel v Truitt, 424 SE2d 660, 661 (NC App 1993); Forest Oaks Homeowners Ass'n v Isenhour, 401 SE2d 860 (NC App 1991). See also Gigowski v Russell, 718 SW2d 16 (Tex App 1986) (upholding the application of a restrictive covenant against mobile homes to a double-wide manufactured home, and holding the complainants entitled to an injunction requiring the removal of the home).

159 For treatment of agency costs in business corporation settings, see Michael $\mathrm{C}$. Jensen and William H. Meckling, Theory of the Firm: Managerial Behavior, Agency Costs and Ownership Structure, $3 \mathrm{~J}$ Fin Econ 305 (1976); Eugene F. Fama and Michael C. Jensen, Separation of Ownership and Control, $26 \mathrm{~J} \mathrm{~L} \&$ Econ 301 (1983).

160 Ronald A. Cass, Privatization: Politics, Law, and Theory, 71 Marq L Rev 449, 484 
are some reasons to believe that agency costs would be less substantial for associations than in the cases of corporations or governments. For a variety of reasons, association decision makers may internalize the consequences of their decisions in ways that officials of localities and corporations do not. As indicated above, the homogeneity of the association means that it is less likely that divergent rent-seeking groups will arise in the first place. ${ }^{161}$

Other inducements should reinforce the identity of officials' interests with those of members. The homes of association officials will likely represent a significant percentage of their wealth, so that their interests in maximizing property values by providing proper services and maintaining covenants that define the nature of the association (each of which should be capitalized into property prices) will reflect the interests of other residents. This commonality of interest suggests that there will be fewer competing claims for the votes of decision makers and fewer opportunities for decision makers to seek rents by favoring one group of constituents over another. When those occasions do arise, the fact that decision makers are members of the association means that they are subject to all the extralegal, reputational, and retaliatory consequences that lead all residents of the association, as neighbors, to be attentive to communal rather than personal concerns. Given the relatively small size of the group, deviations from communal interest are likely to be more detectable and more vulnerable to publicity. Since covenants typically affect physical activities, their interpretation by association officials is subject to more rigorous and frequent monitoring than the conduct of either local officials or corporate officers, which may be more concerned with financial or other intangible information that is difficult to obtain. The proximity of neighbors also means that, even though association officers face only occasional elections, their constituents have more constant opportunities between elections to register complaints at low cost. Since constituents face high exit costs (at least as compared to shareholders of firms), ${ }^{162}$ they have substantial incentives to take advantage of

(1988). See also Bernard S. Black, Agents Watching Agents: The Promise of Institutional Investor Voice, 39 UCLA L Rev 811 (1992); William H. Page, Antitrust, Federalism, and the Regulatory Process, 61 BU L Rev 1099 (1981); Cass R. Sunstein, Interest Groups in American Public Law, 38 Stan L Rev 29 (1985).

161 See text accompanying note 120 .

162 See Cass, 71 Marq L Rev at 482 (cited in note 160). 
opportunities to monitor and complain in order to protect their investment.

Additionally, again assuming the relative clarity of the signal sent by covenants, the existence of official misbehavior will be more obvious. For both local and corporate officials, the criteria of a "good" job, or of deviation from constituent interest, are rather opaque. Local officials will face multiple, vague, and sometimes competing objectives, such as fiscal responsibility or fair distribution of local resources, so that measuring the quality of an official's performance is quite difficult. ${ }^{163}$ Corporate officials can be monitored by a single output measure, namely profit maximization. Nevertheless, the level of their success is somewhat beclouded by questions of trade-offs between long-term and shortterm profits, at least to the extent that we reject the achievement of perfect markets in which expected long-term performance is reflected in current share prices. ${ }^{164}$ Violations of covenants should be relatively clear since they deal with physical arrangements. The presence of a prohibited use, a trailer home for example, is evident.

Finally, the rents that officials of associations might seek appear less attractive than rents sought by corporate or government officials. Service as a member of an association board of directors does not return the kinds of benefits that might lead those who occupy management positions in other contexts to maximize objectives other than their constituents' welfare. These are unpaid positions, so, unlike officer or director positions in private corporations, they are likely to have little consequence for financial wealth. Similarly, unlike political or corporate offices, holding such a position does not create much personal publicity or fit within a hierarchy of decision makers, so that nonmonetized rewards such as fame or advancing to a higher position does not hold much attraction.

But if there are no benefits that can be obtained by participation in association governance, why would anyone engage in the activity? While altruism may explain some level of participation, the fact that management does not generate other rewards may suggest that only those with highly idiosyncratic objectives

163 Id at $483-84$.

164 The current critique of management attention to short-term gain suggests that long-term performance is not, in fact, reflected in current share prices. See Robert H. Hayes and William J. Abernathy, Managing Our Way to Economic Decline, Harv Bus Rev 67 (July/Aug 1980); Glen O. Robinson, Probabilistic Causation and Compensation for Tortious Risk, 14 J Legal Stud 779, 784-85 (1985). 
would accept such a position. Since participating in association governance will create public goods in which we would expect participants to underinvest, we would anticipate that association officials become involved in order to direct decision making, particularly expenditure decisions, toward their own unique interests. Since boards tend to be small in size, a single vote may be important to any outcome, so that participation on a board is likely to increase substantially the chances of advancing idiosyncratic preferences. Assume, for instance, that a neighbor believes that a covenant should be interpreted in a particular, if unconventional, way. It may be that the best way to obtain a sympathetic vote of the association is to become a member of the board of directors and either trade votes with other members or rely on the small number of votes to attract the few allies necessary to the desired outcome. Alternatively, individuals may become association officials in order to maximize personal interests unrelated to future objectives or to public service, such as the opportunity to be a "busybody" or to enforce rules for the sake of exercising personal authority rather than to ensure the success of a community ethos.

At the same time, resident monitoring of board members may be less intense than the above argument suggests. While constituents in all organizations face incentives against monitoring, most shareholders can often avoid the implications of free riding because other shareholders have sufficiently high stakes to warrant their monitoring regardless of the inactivity of others. Whether association members can similarly rely on a neighbor with an intense interest in a covenant violation depends on how much more significantly that neighbor is affected than others. One would anticipate that association officials' attention to violations of covenants that restrict loud noises, for instance, would be monitored more closely than violations of covenants that are directed at limiting traffic, such as conducting a commercial enterprise in a home.

One additional point worth considering about agency costs relates to the changes in the governance structure of a community during its life cycle. When a subdivision is first created, the developer will typically retain substantial discretion over its governance. Only after a certain number of units within the subdivision are sold will the developer cede control to the association or its board of directors. The coincidence of the developer's and residents' interests may be as complicated as the incentive structure I have suggested exists between the association and its res- 
idents. The developer desires to market homes within the association, and compliance with the covenants, by defining the nature of the community, serves as a marketing tool to attract residents whose interests are reflected in those covenants. Hence, one would imagine that market-based incentives would induce the developer to interpret the covenants in a manner consistent with the norms of the community. ${ }^{165}$ During the period that the developer believes that its marketing strategy will be successful, there seems little reason for it to deviate from this common understanding.

The problem arises when the developer believes that its initial strategy was mistaken. At this point, the developer may desire to change the terms of the transaction. ${ }^{166}$ Assume, for instance, that the covenants of an association declare that no property shall be used for commercial purposes. After slower-thananticipated sales, the developer, who retains the capacity to interpret the covenants, permits new purchasers to open offices within their homes. Association members who have purchased their homes to this point might object that the restriction on commercial use applies to offices within residences as well as to buildings intended solely for commercial purposes. They might contend that the very concerns about increased traffic and difficulty of policing transients that would apply to a commercial building also apply to a commercial use of a residential building. Given that the developer's interest in maximizing income no longer coincides with existing residents' interest in maintaining a particular type of community, there seems little reason to believe that the developer's unchecked interpretation of covenants will be consistent with existing residents' understanding of those covenants.

${ }_{165}$ See Epstein, 73 Cornell L Rev at 917 (cited in note 67). Compare Ellickson, $40 \mathrm{U}$ Chi $L$ Rev at 681 (cited in note 85) (claiming that covenants drafted by developers could provide more efficient land-use regulations than zoning because developers provide relatively inexpensive alternatives to bureaucratic drafting, while market forces will induce the developer to include only provisions that increase land values in excess of the costs imposed by the constraint). For a response that individuals who are attracted by these covenants are not very successful at predicting their future preferences, see Stewart $\mathrm{E}$. Sterk, Foresight and the Law of Servitudes, 73 Cornell L Rev 956, 957-61 (1988). While Professor Sterk suggests reasons why individuals may not have perfect foresight, he does not purport to establish the proposition that judges will be better able to detect when individuals have changed their preferences or when the law ought to intervene to correct initial decisions made with imperfect foresight.

${ }_{166}$ Frances FitzGerald reports that Sun City, Florida, was originally intended to contain only single-resident housing units, but was changed to include condominiums when the pace of housing sales slackened. FitzGerald, Cities on a Hill at 214 (cited in note 14). 
I cannot readily conclude, therefore, that either the association or the developer will necessarily interpret covenants in a manner consistent with the consensus of association members. Divergence in the views of association officials, however, does not necessarily invite more intrusive judicial scrutiny of covenants. If we believed that courts were adept at identifying those cases in which decision makers had interests that deviated from those of association members, we might direct courts to intervene more readily in those cases. But if courts have no greater ability than association members to discern rent-seeking activity by association officials, there seems little reason to rely on those outside the community to define the scope of community norms as embodied in covenants.

\section{ASSOCIATIONS AND NONRESIDENTS}

The assertion that cooperative norms will emerge within the association and are more readily identifiable and enforceable by members than by courts does not entail that these norms will serve the welfare of those outside the association. ${ }^{167}$ Thus, one negative implication of my argument to this point is that judges should be far more interventionist where associations impose costs on nonresidents. The problem is that this principle, without more, swallows up the argument for judicial restraint. All covenants affect those outside the association, in that they restrict access to prospective home purchasers who prefer the same lifestyle as association residents, except for one (or more) of the covenants. At the same time, there are few situations in which decisions of associations are specifically aimed at nonresidents. ${ }^{168}$ We return, then, to the problem with which we began: determining the latitude that we are willing to confer on groups that seek

167 See Ellickson, Order without Law at 169 (cited in note 124) (noting that norms that advance the welfare of a close-knit group may disserve outsiders).

${ }^{168}$ Matthews $v$ Bay Head Improvement Ass'n, 95 NJ 306, 471 A2d 355, 359 (1984), stands as a notable exception. In that case, an association of property owners sought to exclude nonresidents from a local beach. The court held that the public trust doctrine required access to beachfront property and applied to both municipally owned and privately owned property. The court, however, noted the extraordinary relationship between the association and the borough within which it had been formed. The borough had contributed to the cost of jetties, had provided the association free office space, exempted certain association property from taxation, and had included association activities under borough insurance policies. Id at 365-68. See also MaJor v Miraverde Homeowners Ass'n, 7 Cal App 4th 618, 9 Cal Rptr 2d 237, 241-43 (1992) (enjoining a rule that limited access to recreational areas of an association by nonresident owners). 
some degree of isolation, notwithstanding that their private arrangements affect nonmembers.

The polar case for judicial intervention exists where the association seeks to engage in conduct that could not constitutionally be enforced with the participation of state actors. ${ }^{169}$ Here, the externality may take the rather intangible form of affecting even those who are not directly excluded, because the basis of exclusion makes them uncomfortable about living in a society where such exclusions are practiced. ${ }^{170}$ Less clear is which outcome is preferable when the association seeks to enforce a covenant that does not offend constitutional principles, but that is inconsistent with other social norms. In these cases, our willingness to allow the association to set itself up against the broader society reflects our reaction to the kind of diversity that I suggested at the outset underlies Chief Justice Burger's opinion in Schad. ${ }^{171}$ The desire for heterogeneity implicit in those remarks finds resonance in the sociological literature that urges the development of community by allowing greater autonomy for localities:

[T] he legal tendency is to assume that there is a unitary national community rather than a national community composed of thousands of communities. Thus, the people of Kokomo, Indiana, must accept public promotions of pornography, for instance, because such promotions are protected by precedents established in Berkeley, California, or in Times Square. It is just barely arguable that the person who wants to see a live sex show in downtown Kokomo would be denied a constitutional right were such shows locally prohibited. It is a great deal clearer that the people of Kokomo are now denied the right to determine democratically the character of the community in which they live. More careful distinctions are required if we are to stay the rush toward a situation in which civil liberties are viewed as the enemy of communal values and law itself is pitted against the power of people to shape their own lives. ${ }^{172}$

169 See Note, Judicial Review of Condominium Rulemaking, 94 Harv L Rev 647, 65658 (1981). See also Laguna Publishing Co. $v$ Golden Rain Foundation of Laguna Hills, 131 Cal App 3d 816, 182 Cal Rptr 813, 829 (1982).

${ }_{170}$ So, for instance, a racial restriction may adversely affect even those who are not members of the restricted race because they are not indifferent to living in a race-neutral society.

${ }^{171}$ See text accompanying notes 2-6.

172 Peter L. Berger and Richard John Neuhaus, To Empower People: The Role of Medi- 
Some courts that have rejected intrusive interpretations of covenants, notwithstanding that enforcement creates adverse effects for nonresidents, appear at least implicitly to endorse the same view. Other courts, however, appear to seize on the conflict between covenants and conflicting social policies either explicitly to abrogate the private covenants or to entertain narrow constructions of them. ${ }^{173}$

Analysis of these cases may provide some hints toward a theory of when association activity generates sufficient effects on nonresidents as to require intervention. Consider, for instance, the issue of whether prohibitions in covenants on the operation of businesses within the association or limitations of occupancy to "single-family" residences can be enforced to prohibit group homes. ${ }^{174}$ Several courts have recognized that a restrictive definition of residence or family that requires blood or marital relationships between the occupants is inconsistent with state policies in favor of the creation of group homes, where individuals live together and either care for each other or are cared for by a common supervisor. ${ }^{175}$ Other courts have upheld the association's restrictive definition of residence or family to more traditional forms. ${ }^{176}$

The highwater mark for the latter position appears to have been reached in Clem $v$ Christole, Inc. ${ }^{177}$ In that case, residen-

ating Structures in Public Policy 11-12 (American Enterprise Institute, 1977).

${ }_{173}$ In Baldwin v Nature's Hideaway, Phase I-B Homeowners Ass'n, 613 S2d 1376 (Fla App 1993), for instance, the court found that an adult foster care home was not prohibited by a covenant restricting businesses within the association because no nuisance was shown. A provision of the covenants indicated that no activity that constituted a nuisance could be carried on within the association. The court read the prohibition on businesses to be subject to the "no nuisance" clause rather than reading the prohibition on businesses as an independent clause. The court recognized, but did not decide the effect of, a state statute overriding local laws and ordinances restricting residences to single-family units. Id at 1377-78. See also Double D Manor, Inc. $v$ Evergreen Meadows Homeowners' Ass'n, 773 P2d 1046, 1048 (Colo 1989) (interpreting a restrictive covenant on single-family residences as only a structural, not a use, restriction); Prien Oaks Homeowners Ass'n v Mocklin, 560 S2d 115, 117 (La App 1990) (interpreting an ambiguous distance requirement between fences and the "waterfront line" so as to impose the fewest restrictions on the property).

174 See Brussack, $16 \mathrm{Ga} \mathrm{L} \mathrm{Rev} \mathrm{at} 34$ (cited in note 43); Thomas F. Guernsey, The Mentally Retarded and Private Restrictive Covenants, 25 Wm \& Mary L Rev 421 (1984).

175 See, for example, Baldwin, 613 S2d at 1377; Double D Manor, Inc., 773 P2d at 1051-52; Turner $v$ United Cerebral Palsy Ass'n, 772 P2d 628, 630 (Colo App 1988) (group home constitutes a family); Vienna Bend Subdivision Homeowners Ass'n v Manning, 459 S2d 1345, 1348-50 (La App 1984) (same).

${ }_{176}$ See, for example, Mains Farm Homeowners Ass'n $v$ Worthington, 121 Wash 2d 810, 854 P2d 1072, 1075-76 (1993).

${ }_{177} 582$ NE2d 780 (Ind 1991). See also Minder v Martin Luther Home Foundation, 582 
tial subdivision property owners sought to prevent the creation of a group home for developmentally disabled individuals within the subdivision. Covenants that governed the subdivision prohibited the use of buildings "for business or commercial purposes of any kind" and restricted the use of lots within the subdivision to "single-family or two family dwellings." The fact that the association's preferences were inconsistent with those of the larger society were arguably evident from the fact that the state legislature had enacted a statute (subsequently repealed) that invalidated such restrictive covenants. ${ }^{179}$ The court declared that the statute violated the contracts clause of the state constitution, insofar as it applied to preexisting restrictive covenants. The court considered such covenants to be issues of private concern, rather than of public policy. ${ }^{180}$ While disruption of private contractual expectations might be warranted to satisfy an important social problem, and while prospective application of the prohibition might be appropriate, the problems of housing the developmentally disabled did not offset the substantial costs that would materialize should restrictive covenants be negated:

Restrictive covenants permit property owners to collectively provide or obtain protections significantly contributing to the peace, safety, and well-being of themselves and their

NE2d 788 (Ind 1991).

178 Clem, 582 NE2d at 782.

179 Id. The statute provided:

(a) This section applies to each restriction, reservation, condition, exception, or covenant that is created before April 1, 1988, in any subdivision plat, deed, or other instrument of, or pertaining to, the transfer, sale, lease, or use of property.

(b) A restriction, reservation, condition, exception, or covenant in a subdivision plat, deed, or other instrument of, or pertaining to, the transfer, sale, lease, or use of property that would permit the residential use of property but prohibit the use of that property as a residential facility for developmentally disabled or mentally ill persons:

(1) on the ground that the residential facility is a business;

(2) on the ground that the persons residing in the residential facility are not related; or

(3) for any other reason;

is, to the extent of the prohibition, void as against the public policy of the state.

Ind Code § 16-13-21-14 (1988), repealed by Ind Pub L No 9-1991 § 98 (May 12, 1991).

${ }^{180}$ The law must not be arbitrary, unreasonable or patently beyond the necessities of the case. The legislature may not under the guise of protecting public interests arbitrarily interfere with private business or impose unnecessary restrictions upon lawful occupations.

Clem, 582 NE2d at 783, citing Dep't of Financial Institutions $v$ Holt, 231 Ind 293, 108 NE2d 629, 634 (1952). 
families. These purposes are consistent with values identified in our Indiana Constitution. Article 1, Section 1 expressly recognizes that government is instituted for the peace, safety, and well-being of the people. Article 1, Section 31 protects the right of citizens to assemble together in a peaceable manner to consult for their common good. ${ }^{181}$

At first glance, the decision appears to elevate private agreements above what would be required by the analysis that I have suggested, that is, judicial deference to the relational process that incorporates the views of all those affected by the decision. There is certainly no reason to believe that the developmentally disabled were represented in the creation or interpretation of the restrictive covenant at issue. Nor is it easy to find a surrogate for them within the association, at least not in a case like Clem where the purchaser of the home had not previously been an association member. ${ }^{182}$ Perhaps sellers who wish to maximize their sale price and who (as a result of the fact that they are selling) no longer bear a reputational burden within the community can serve as surrogates for group home operators. But my prior analysis suggests that sellers who act in this manner, as well as residents who transform their homes into group residences, may simply be rejecting the ethos of the community as reflected in the covenants; they have changed their minds about the initial deal. Thus, Clem directly asks the question of how to resolve our ambivalence about conflicts between the preferences of those within and without the association.

One way to sort out when the adverse effects are sufficiently substantial to warrant intervention is to ask whether we are confident that the conflicting social policy actually reflects a consensus of the broader society. Principles that reach constitutional proportions do so in large part because they reflect the deeply held views of a substantial segment of the population. Thus, when we reject private arrangements that conflict with constitutional principles, we may feel comfortable that we are properly imposing a majoritarian conception of what is necessary to pursue the good life for society as a whole. Statutory embodiments of public policy may be more suspect. For instance, I suggested above that the presence of a statute in Clem prohibiting restrictions evinced a state-wide view in favor of integrating group 
homes into traditional neighborhoods. It is possible, however, to tell a somewhat convincing public-choice story about the same legislation. According to this story, activists for the mentally ill were able to capture the state legislature, notwithstanding that their views did not reflect those of the state as a whole. State legislation would generate less resistance than local ordinances, since the state-wide effect of the prohibition would be too diffuse to make it worthwhile for local opponents to coalesce. At the same time, associations that may have significant influence at the local level are unlikely to have comparable access to state legislative processes. Thus, they would be unable to counterbalance interest-group politics at the state level. If we believe this story, then the enforcement of covenants, far from countering majoritarian influences, serves as an anticapture device for those who are less prone to protect themselves against interest-group politics. In Clem, for instance, if we believe that the interestgroup story offers a more compelling explanation for the legislation, then we might consider the decision to uphold preexisting covenants as an effective weapon to blunt the effects of interestgroup capture. ${ }^{183}$

This anticapture rationale makes the most sense when the association seeks an exemption from a generally applicable requirement, as in Clem. Yet even within this subset of cases, the anticapture justification perhaps grants too much autonomy insofar as it suggests that associations can receive an exemption from ordinances or statutes simply by adopting contradictory covenants. Thus, exemptions might make sense only in those cases where judges detect a reasonable likelihood that the conflicting legislation resulted from capture. It should not be surprising, therefore, if courts reject claims that associations are exempt from municipality-wide zoning plans, because such an exemption cannot easily be explained by capture.

More commonly, however, covenants involve efforts by an association to create restrictions that are not directly addressed one way or the other by the locality or the state. We would expect this type of case to arise frequently if I am correct that a primary function of associations is to allow privatized regulatory schemes that are more tailored to residents' preferences than municipal

183 The argument here creates a parallel in the association/local relationship to Tocqueville's contention that decentralized municipal government would provide some shelter for liberty even in periods of centralized oppression. Alexis de Tocqueville, Democracy in America 262-63 (Anchor, 1969) (J.P. Mayer, ed). 
regulation. Even if we are willing to recognize some value in this objective, we would expect some nonconstitutional limits on its pursuit, given the consequences for nonresidents and the fact that even municipal corporations have only limited ability to impose adverse effects on nonresidents. ${ }^{184}$ While the permissible level of these externalities is hard to define, one might infer from judicial reaction to the group-home cases that the limitations on association autonomy depend on whether enforcement of the covenant at issue excludes in a manner that substantially impairs the mobility of those excluded.

Under this analysis, the question of whether to trump covenants can be viewed in traditional prisoner's dilemma terms. These consequences may best be seen by considering the policies of cities rather than associations. Group homes, for instance, may be considered undesirable by most municipalities. ${ }^{185}$ Hence, if we allow a municipality to reject siting of such land uses, most municipalities will prohibit them. Under these circumstances, municipalities that might accept a "fair share" of such homes would fear that they will end up accepting all of them if other localities proscribe such uses. Thus, even municipalities otherwise willing to accept their "fair share" have incentives to join in the ban. Universal prohibition on such bans may therefore be necessary in order to locate group homes anywhere. This logic does not necessarily mean that private arrangements among multiple parties should be abrogated. If localities are required to accept such land uses, they can fulfill that obligation by locating the uses outside of associations. Within the locality, however, the effects of this conclusion would lead to the same perverse results that govern interlocal relationships. In the absence of a requirement that all parts of the locality accept group homes, any neighborhood, including those willing to accept a "fair share" of the homes, will seek to prohibit them for fear that others will do so. The fact that communities with covenant regimes will have an easier time avoiding such uses than other parts of the locality

184 Holt Civic Club v Tuscaloosa, 439 US 60, 69-70, 75 (1978), may be cited for the proposition that municipalities can impose costs on nonresidents. But without express authority, localities do not have extraterritorial regulatory power. Questions of municipal boundaries typically require examination into whether the locality is imposing costs on those outside the suggested boundaries. Finally, municipal decisions that affect nonresidents are typically subject to market constraints that do not apply as readily to homeowners associations. For instance, municipalities that seek to impose commuter taxes must take into account the possibility that commuters can shop and work elsewhere.

${ }^{285}$ See Vicki Been, What's Fairness Got to Do With It? Environmental Justice and the Siting of Locally Undesirable Land Uses, 78 Cornell L Rev 1001, 1001-02 (1993). 
may mean that associations suffer fewer undesirable land uses. Remaining residents of the locality will presumably attempt either to create their own contractual arrangements to bar such uses or to seek a locality-wide ban. Judicial refusal to enforce covenants that have such effects serves as a mechanism for breaking out of the prisoner's dilemma that exists where numerous localities or areas of the same locality would, if left to their own devices, reject the same individuals. Conversely, judicial enforcement of covenants that affect nonresidents may be appropriate where there remain "enough" areas to which those excluded by the covenant can migrate. ${ }^{186}$

Focus on the extent of the exclusion may be seen as a corollary to the Lockean proviso that permits individuals to retain the fruits of their labor as long as there remains "enough and as good left in common for others." ${ }^{187}$ Exclusion from an idiosyncratic community permits the members of that community to realize their interests without significantly penalizing those who are excluded. As the number of communities who endorse the same exclusion multiplies, however, the mobility of the excluded may become so constrained as to trump the interests in upholding the exclusion. This explanation may help us to understand why we might have different reactions to the same exclusion, depending on its source. If private individuals enter into a contract to exclude those with certain characteristics from their homes, we might have little concern for its effects on the excluded, since the scope of the contract is limited in space and time. While the same contract could theoretically be entered into by an infinite number of people, that event seems unlikely (as evidenced by the transaction-cost explanation for covenants). Once covenants cure that collective-action problem, however, the likelihood that substantial numbers of people will join such a covenant and will commit future generations to the same proposition causes more concern. Should we elevate the scope of the covenant further by allowing state entities to cure the collective-action problem (by passing laws embodying the exclusion, thus increasing the geographical scope of the exclusion and giving it the force of legal sanction), we would make the effects of the exclusion even more difficult to avoid.

${ }^{186}$ See, for example, Mains Farm Homeowners Ass'n, 854 P2d at 1077-78.

187 John Locke, Second Treatise on Government $\$ 27$ at 19 (Hackett, 1980) (C.B. Macpherson, ed). 
This distinction between permissible and impermissible exclusions provides a justification for allowing a community to impose its preferences on outsiders where the basis for exclusion does not substantially constrain the mobility of those excluded. In reasoning to this conclusion, I have also indicated that local political forces to exclude a particular group or land use might be so prevalent throughout society as to justify universally invalidating the effects of those forces-both in associations and in more traditional governmental units. Once we focus on political action, however, there may follow a stronger justification for allowing affirmative exclusions by associations, a justification that follows from a claim of political equality between those who live within and without associations.

I assumed above that those who live in neighborhoods not governed by covenants will nevertheless be able to influence local officials and thus will be able to procure locality-wide bans on undesirable activities. This assumption suggests that the absence of covenants does not necessarily place these individuals at a political disadvantage. Rather, they may achieve their community norms by participating in political processes on an ad hoc basis. The decision not to live within an association may therefore indicate a preference for ad hoc political activity rather than for ex ante regulation.

For instance, one might expect that in any locality, resolution of controversial issues such as siting of group homes will necessitate some form of bargaining between the locality and the areas potentially available for the disfavored use. Neighborhoods in which coalitions can form to oppose the siting or to bargain with the locality may do better in avoiding these uses or in obtaining compensation for accepting them than neighborhoods in which coalitions have more difficulty forming. ${ }^{188}$ If those who live in associations have an entitlement to enforce covenants that prohibit uses available elsewhere in the locality, local officials who wish to site those uses in the association will bear the burden of beginning the bargaining process, while residents of neighborhoods outside of associations will bear the burden of beginning the bargaining process with local officials. This ostensible disparity becomes more appropriate if we believe that those who live in associations are systematically less effective at creating coalitions to oppose or influence municipal action.

${ }^{188}$ See Been, 78 Cornell L Rev at 1002 \& n 6 (cited in note 185). 
At first, this conclusion seems counterintuitive. Indeed, the very existence of the association suggests that a collective body exists, so coalition costs are lower. In addition, some instances of association action against municipal conduct do exist, such as where associations seek to enjoin the application of local ordinances. ${ }^{189}$ The fact that an association is effective at regulating relations among members, however, does not indicate similar success in dealing with outsiders. Although there is some evidence that associations maintain contact with local officials, ${ }^{190}$ that same evidence suggests that members are not systematically involved in local public affairs. Because association voting schemes do little to foster participation even in association affairs, ${ }^{191}$ migration to an association may indicate a relative inability or unwillingness to participate in the politics of the diverse world outside association boundaries. After all, it seems somewhat anomalous to assume that association members migrate to a common area in order to seek isolation within homogeneity and to live by highly tailored, privatized regulations, and simultaneously to assume that they seek the robust debate of a diverse political marketplace. Perhaps this distaste for politics outside the association also explains the otherwise anomalous phenomenon that associations receive little statutory protection. One would imagine that groups of associations, composed of a limited number of readily identifiable units with concentrated populations that can be easily monitored, would make effective lobbying groups for issues of common concern, such as avoiding double taxation and obtaining reimbursement of privately provided public services. ${ }^{192}$ While I am reluctant to infer too much from the failure of associations to organize for legislatively granted benefits, the presence of such legislation would defeat the hy-

189 See cases cited in note 83 . There is some evidence that association members believe that they and their associations are more attentive to local political affairs. See Dilger, Neighborhood Politics at 134-35 (cited in note 1). The basis for this supposition is unclear.

190 Id at 135.

191 See id at 139-141.

192 Residents face double taxation insofar as the association must pay property taxes, funded by assessment imposed on individual lots, on common areas that the association owns. At the same time, individual residents pay property taxes on the value of their homes, which value also reflects the availability of the common areas. See ACIR Report at 18 (cited in note 1). As noted above, see note 70, there is little statutory basis for reimbursement to associations for privately provided services that the locality would otherwise be required to provide to residents. It is possible that the absence of these protections is evidence of the relatively new popularity of associations rather than the systematic unwillingness of residents to participate in the traditional political marketplace. 
pothesis that association members have less taste for the political marketplace than exists outside the association.

This view is also consistent with my prior claim that associations constitute enforcers of private rules for those who have opted out of governmental decision making. If association members are relatively poor lobbyists for their interests in their interactions with local governments, and if we want to ensure that local governments have no more ability to impose the costs of social programs on residents within associations as on those without, we might assign entitlements differently to those two groups. Granting latitude to covenants might serve as an equalizer that compensates for the relative unwillingness of association members to bargain for a fair share of undesirable land uses that must be spread throughout the locality.

\section{CONCLUSION}

Residential associations may be easy targets. Their attraction is frequently based on mundane aspects of the good life rather than on the creation of robust communities. They tend to exclude those worst off in the society. They impose costs on their members who seek to avoid restrictions and on outsiders who may have to bear a greater level of undesirable activities and land uses that are excluded from the associations. Nevertheless, I have suggested that they may fulfill important functions and do so in a manner that entitles their decisions to substantial deference in a wide range of cases. Whether associations realize this potential depends on such issues as their ability to signal a common lifestyle to potential members and the susceptibility of their officials to interests inconsistent with those of their members. On some of these issues, I remain agnostic. But the overall picture I have attempted to paint is of a mechanism for sorting that is no more invidious than we allow through the creation of more formal jurisdictions (municipal corporations) and that is more responsive than those institutions to the desires of residents. That these smaller jurisdictions may engage in activities that set them apart from others in society is undeniable. But that is a source for further analysis, not a conclusion that necessarily leads to denigration of these institutions. 
